\title{
Mircea Eliade'de Kutsal Kavramı Analizi ve Bir Metalaşma Unsuru Olarak Mevlid Kandili Örneği*
}

\author{
The Analysis Of The Concept Of Holy In Mircea Eliade And The Example Of Mawlid An-Nabi As A \\ Commodification Element
}

\author{
Hatice Erdem $^{* *}$
}

\begin{abstract}
The phenomenon of holy time, which appears in different ways in almost all the religious traditions, has arisen with the ritual application of certain days and nights considered holy in today's Muslim societies. Celebrations and ceremonies organized due to the birth of Prophet Muhammed (S.A.V.) are held under the names of "Holy Birth" and "Mawlid al-Nabi" as an expression of the love and respect for him. The aim of this article is to examine the relationship between "holy" and "non-religious/profane" attributed to holy nights over the "holy" concept analysis of Mircea Eliade, who conducted studies on the history of religions, and to investigate how the religious ceremonies held at holy nights are reflected on the religious beliefs of the individuals within the daily life. Qualitative research technique was used in the research and focus group interviews were conducted with a group of participants. The sampling of the study consists of 13 students studying in the undergraduate and graduate fields of Istanbul Sabahattin Zaim University. In this context, it was approached and interpreted within the frame of the empirical findings to what extent the activities of the Holy Birth Week, which constitute the field of study of specifically the research, holistically the holy nights, brought the individuals of the society together, to what extent the consumption society and religious values were subjected to commodification through celebrations and symbols, to what extent the religious rituals eliminate and develop the conflicts and otherization in the society. Accordingly, it was revealed that celebrations and religious symbols are manifested in the form of individual experience of religion, which is a sacred reality which individuals approach with pre-assumptions. The Mawlid tradition has been perceived as an indicator of loyalty to the teachings of Prophet Muhammed (S.A.V.), respect for his divine duty and piety.
\end{abstract}

Structured Abstract: The phenomenon of holy time, which manifests itself in different ways in almost all religious traditions, is either expressed by God in a verse of the holy book, or later sanctified with religious acceptances becoming ritual through people. In the first one, there is a reference to a value directly pointed out by God or a sacred value stated by the prophets he sent, while in the second one there is an attribution of holiness to time. This holiness is manifested mainly as a socio-cultural need or by the satisfaction of religious feelings. Examples of the first one are the Passover days mentioned in the Old Testament for Jews, the month of Ramadan and the Night of Power being mentioned in Qur'an and considered as sacred, and celebration of Christmas by Christians. Examples of the second one are the Islamic holy nights, which are celebrated by

\footnotetext{
* Çalışmada kullanılan veriler 2020 yılından önce elde edilmiştir.

*** Yüksek Lisans Öğrencisi, İstanbul Sabahattin Zaim Üniversitesi, Sosyal Bilimler Enstitüsü MA Student, İstanbul Sabahattin Zaim University, Institute of Social Sciences, Sociology ORCID 0000-0002-8357-4311

hatice@islamoglu.net

Cite as/ Atıf: Erdem, H. (2020). Mircea Eliade'de kutsal kavramı analizi ve bir metalaşma unsuru olarak mevlid kandili örneği. Turkish Studies - Education, 15(3), 1799-1828. https://dx.doi.org/10.29228/TurkishStudies.40169

Received/Geliş: 14 December/Aralık 2019

Accepted/Kabul: 21 June/Haziran 2020

Checked by plagiarism software

Copyright (C) INTAC LTD, Turkey 
Muslims, and the Feast of the Immaculate Conception on March 25, on which Mary (pbuh) is believed to have conceived Jesus (pbuh) (Bible/Luke 1:26-38).

In this context, Eliade made an effort to form a religious theory in general terms. Thesis of Eliade, who addresses the concept of holiness/sacred in his studies, examines the concept of holiness in religions. According to him, the sacred is an upper element to which all religious elements are attached to (Demirci, 1997). In his basic thesis for achieving a universal phenomenon of religion, Eliade discussed the relationship between religious thought and traditions through the religious human profile of archaic societies. Based on the feeling that reveals the religious people's understanding of existence and reality, he defines the sacred as an element in the structure of consciousness, not as a stage in the history of consciousness (Eliade M. , 2014).

"Homo religious", which is a concept that expresses the principles of faith in ancient and modern religions, is defined as an innate and instinctive feeling, which is the basis of the sense of religion and religiosity, of human life (Ünver, 2004). How and in what way abstract concepts such as faith/belief will function will emerge through the examination of the equivalents of religious practices in current life Due to the fact that religious phenomena in ancient religions consist of elements determined by the rules. This method also applies to the transfer of practices from generation to generation in revealed religions. The Prophet (pbuh), a living witness of revelation teachings, comes up as an active founder and constructing subject, taking the source from the origin, as an actual example of revelation. The concept of "sacred" that underlies the cultures formed in the framework of religion in the later periods, put the mission and practices of the Prophet (pbuh) into the rituals of daily life and made it the subject of mythology. The mythological Prophet conception has been a product of misunderstanding the existing truth and has led to the fetishization of everything attributed to him by depriving them of their mission.

Today, the Mawlid tradition is celebrated officially in some of the Islamic countries and unofficially in others from North Africa to Indonesia (Özel, 2004). In Turkey, Mawlid night is celebrated every year with mawlidhans under the name of cultural and artistic activities of mosques, foundations, associations and municipalities as the manners of worship within the kandil (holy night) tradition. On these nights, the Qur'an, Süleyman Çelebi's Mawlid, hymns, qasidas and poems are recited. The fact that the Directorate of Religious Affairs has fixed the mawlid celebrations, formerly known as the "Blessed Birth Week", to one day under the name of "Mawlid-i Nebi" and organized programs with special events for that day, has placed the night in the category of religious days and nights accepted by the community.

All religious attitudes and behaviors are an effective force in determining the thoughts and attitudes of individuals throughout history and their relationship with one another, which is the actual manifestation of their behavior. Where societies exist, religious ties have been the main factor that holds them together. This strong relationship between religion and society derives its functionality from the continuity of religious rituals and traditions that hold societies together. These ceremonies, rites and rituals, which preserve the dynamic structure of the historical religions, led the individuals to meet in a common denominator. In this sense, the unifying and integrating power of rituals is an undeniable fact. However, while performing these ceremonies and rituals, it should be remembered that the Qur'an is the most objective, original and authentic source from which we can learn about the Prophet (pbuh). Because there is no distance between the Prophet and the Qur'an. We understand the revelation through/by means of him. If the means are misunderstood, he, who is the greatest guarantee of the correct understanding of the revelation, will be injured.

Belief systems, widely accepted in the cultural background of societies, consist of the sum of behaviors that are the product of religious perceptions and understandings of different social and cultural environments. While these behaviors play an active role in determining the functionality of religious life in society, they also contain an aspect that ignores the actual purpose to be understood. Therefore, ceremonies that are considered sacred in all religions of history contain an element that reveals the ability of materialization, exaltation, glorification, ennobling, superhumanization, spiritualization and ritualization.

In this sense, in this study, where we will reveal the social components of the mawlid celebrations, it is necessary to clearly and comprehensively reveal the meanings that individuals place on concepts such as sacred-profane, reasonable-illogical, logos-mythos, tradition-ritual, truth-myth in order to accurately determine the correct perspective for understanding the Prophet. The perception of the Prophet, which was fictionally transformed into a mythological hero by the conception of the Prophet revealed by the truth, produced a wideranging mawlid literature. This body of knowledge of Mawlid-i Nebi, which has been expanding year by year 
through the Mawlid celebrations, gaining legitimacy among groups from all walks of society as a sacred and untouchable value by depriving it from its meaning value is very important for understanding the connection of Muslim societies with the sacred.

Keywords: The History of Religions, Holy, Holy Time, Ritual, Religion, Holy Night, Commodıficatıon, Holy Birth

Öz: Dini geleneklerin hemen hemen hepsinde farklı şekillerde tezahür eden kutsal zaman olgusu, günümüz Müslüman toplumlarında kutsal kabul edilen belirli gün ve gecelerin ritüel olarak uygulanması ile ortaya çıkmıştır. Hz. Peygamberin doğumu vesilesi ile yapılan kutlama ve törenler ona duyulan sevgi ve saygının bir ifadesi olarak 'Kutlu Doğum', 'Mevlid-i Nebi' faaliyetleri adı altında gerçekleşmektedir. Bu makalenin amacı dinler tarihi alanında çalışmalar yapan Mircea Eliade'nin 'kutsal' kavramı analizi üzerinden kandil gecelerine atfedilen 'kutsal' ile 'dındışı/profan' arasındaki ilişkiyi sorgulayarak kandil gecelerinde uygulanan dini törenlerin, bireylerin günlük hayat içerisinde dini inançlarına nasıl yansıdığını incelemektir. Araştırmada nitel araştırma tekniği kullanılmış olup bir grup katılımcı ile odak grup görüşmesi yapılmıştır. Çalışmanın örneklemi İstanbul Sabahattin Zaim Üniversitesi lisans ve yüksek lisans alanlarında eğitim gören 13 öğrenciden oluşmaktadır. Bu bağlamda bütünde kandil gecelerinin özelde araştırmanın kendi çalışma sahası olan Kutlu Doğum Haftası etkinliklerinin toplumdaki bireyleri ne ölçüde birleştirdiği, tüketim toplumunun dini değerlerin kutlama ve semboller aracılığı ile ne ölçüde metalaştırmaya tabi tutulduğu, dini ritüellerin toplumdaki çatışma ve ötekileştirmeleri ne ölçüde giderdiği ve geliştirdiği ampirik bulgular çerçevesinde ele alınarak yorumlanmıştır. Buna göre kutlama ve dini sembollerin, bireylerin ön kabullerle yaklaştığı kutsal bir gerçeklik olan dinin bireysel tecrübe edilmesi biçiminde tezahür ettiği ortaya çıkmıştır. Mevlid geleneği Hz. Peygamber'in öğretisine sadakatin, onun ulvi vazifesine bir saygının ve dindarlığın bir göstergesi olarak algılanmıştır.

Anahtar Kelimeler: Dinler Tarihi, Kutsal, Kutsal Zaman, Ritüel, Din, Kandil, Metalaşma, Kutlu Doğum

\section{Giriş}

İnsanın kendisini ve yaşadığı çevreyi anlamlandırması için kavramlara ihtiyacı vardır. Tarihin her döneminde varoluşsal kaygılarla anlam arayışı içerisine giren bireyler bu ihtiyaçlarını dinsel ve kültürel unsurlar aracılığı ile gidermişlerdir. Zamanın veya mekânın iyi-kötü olması bireylerin ona yükledikleri anlama nispetle ortaya çıkmaktadır. Bu bağlamda kutsal tarihsel ve toplumsal bir fenomen olarak algılanmalıdır. Eliade insanın kendisini dindışı olandan tamamen farklı bir şekilde göstermenin yolunun kutsal ile kutsal olmayanın (profan ve dindış1) bilincine vararak onu anlamak olduğunu ifade eder. "En ilkellerinden en gelişmiş tüm dinlerin tarihinin, kutsal gerçeklerin açığa çıkmaları aracılığı ile kutsalın tezahürlerinin birikimi" olduğunu belirtir. Tıpkı kutsalın herhangi bir nesnenin, bir taşın veya bir ağacın içinde ortaya çıkmasından, bir Hristiyan için Tanrı'nın İsa'da bedene bürünmesi cinsinden yüce bir kutsalın tezahürü gibi süreklilik arz eden sahneleri betimler. Bu kutsal görünüm bizim dünyamıza ait olmayan bir gerçeğin "doğal", "dindışı" dünyamızın ayrılmaz bir parçası olan nesneler içinde açığa çıkması ile tezahür etmektedir (Eliade M. , 1995).

Dinlerin hemen hemen tamamında kutsal ilişkili olduğu fenomenlere bağlı olarak dört kısma ayrilmaktadır (Demirci, 1997):

1. Kutsal Mekânlar: Çoğunlukla hierofonik (tabiat üstü bir gücün herhangi bir yerde görünüşüyle ilgili) gerekçelere bağlı olarak bazı coğrafyalarda tabu olarak korunmuş kutsal mekânlardır. Bu mekanlara temas özel ritüelleri gerektirmektedir. Bu tür mekânlar bireylere dünyevî ve uhrevî imtiyazlar kazandırır. Hac mekânı, Mescid-i Aksâ, tapınaklar bu türün örnekleridir.

2. Kutsal Zamanlar: Y1lın belli dönemleri profan sürelerden farklı olarak ortaya çıkmış özel periyotlardır. Modern terminolojide bayram olarak ifade edilen kutsal 
zamanlar, bir takım özel ritüelleri gerekli kılmaktadır. Bunun monoteist dinlerdeki en güzel örneği Yahudilik’teki Şabat kutlamalarıdır.

3. Kutsal Varlıklar: Başta Tanrı olmak üzere doğaüstü olduğunu inanılan varlık türleridir. Bu varlıkları kutsallıklarını uhrevî güçlerinden alırlar.

4. Kutsal Nesneler: Tabiatüstü güç taşıdıkları gerekçesiyle başta asâ türleri, taşlar, kutular, elbiseler ve yüzük olmak üzere çeşitli nesneler pek çok kültürde kutsal kabul edilirler.

$\mathrm{Bu}$ girişten sonra bizim makale konumuzun ana temasını oluşturan kutsal zamanlar üzerinde duracağız. Dini geleneklerin tezahürü olan kutsal zamanların farklı şekiller ve zamanlarda ortaya çıkması kendisini iki şekilde var etmiştir. Kutsal olan ile kutsal olmayan yani "profan-kutsal" üzerinden yapılan bu ikili ayırımda belirli bir zamana atfedilen kutsallık ya Tanrı tarafından kutsal kitaplarda belirtilmesiyle ya da peygamberler aracılığı ile bulunduğu topluma aktarılmıştır. Buradan yola çıkarak kutsallığın dini tanımlamada tanrısal olanın bir özelliği olarak öne çıktığını söyleyebiliriz. İlkel ve antik toplumlarda kutsal ve profan/dindış1 şeklinde yapılan ayırım, kutsalı sıradan hayattan ayırmıştır (Sharpe, 2000).

En basit dinlerde dahi kutsal varlıkların en temel görevinin olumlu eylemle hayatın normal seyrine devam etmesini sağlamak olduğunu ifade eden Fransız sosyolog Emile Durkheim, gizem düşüncesini yeni bir olgu olarak görmez. Gizem düşüncesinin insanda doğuştan var olan bir düşünce olmadığını, insanın bu düşüncenin aksini de meydana getirdiğini, bu sebepten ötürü gelişmiş dinlerin çok azından gizem düşüncesinin önemli bir rol oynadığını ifade eder (Durkheim, 2005).

Kutsal ile ilgili en etkili tanımlamalardan biri de Rudolf Otto'ya aittir. Ona göre insanlığın dini anlamdaki tüm tecrübelerinde ortak unsur kutsal kavramıdır. Kutsalın dinin temeli olduğunu ve ancak din, insan ve kültür etkileşimiyle kutsala farklı anlamlar atfedildiğini ifade eder. Otto, kutsalın tecrübesini benzersiz, eşsiz, tamamen farklı, ayrı ve bambaşka olarak tanımlar. Kutsalın, insan tecrübesinde ontolojik bir duygu kategorisini teşkil ettiğini ifade eder (Allen, 1996).

Eliade'a göre kutsal, inanan insana kendisini din dışı olandan tamamen farklı bir biçimde hissettirmektedir. Ancak, kutsal görünen dünyada saf şekliyle bulunmadığı için, onu çeşitli sosyokültürel ortamlar aracılığı ile farklı formlar içinde algılayabilmek mümkündür. Kutsalı kutsal olmayan ile ayıran nitelikler burada devreye girmektedir. Ona göre herhangi bir şey kendi kendine kutsal değildir. Kutsalın tezahürü; zamanı ve mekânı ya da diğer şeyleri din dışı olandan farklı bir statüye getirildiğini ortaya çıkmaktadır (Eliade M. , 1991). Eliade'de insan dindar (homo religious) olarak tanımlanırken, onun sadece aşkın boyutu ile değil, tecrübe edilen tezahürleri ile ilişkisi de ön plana çıkartılarak analiz edilmeye çalışılmaktadır (Arslan, 2002).

Eliade'de kutsal mekân düşüncesi, mekânın kendisine bir sınır çizilmesi ile ve onu etrafındaki kutsal olmayan mekândan soyutlayarak kutsamış olan ilkel hiyerofaninin yinelenmesi düşüncesi üzerine kuruludur. Kutsal mekânın kutsallığı, onu ilk kez kutsayan hiyerofaninin sürekliliğinden dolayıdır. Hiyerofani, yalnızca farklılaşmış bir kutsal olmayan mekânın belli bir bölümünü kutsamaz; burada kutsallığın devamlı olacağını da garantiler. Böylece mekân, tükenmez bir güç ve kutsallık merkezi haline gelir, herhangi bir insan, buraya dahil olabildiği ölçüde bu güçten pay alabilir, kutsallıkla dolabilir. Bu mekanlar ne kadar çeşitli olurlarsa olsunlar hepsinin tek bir ayırt edici özelliği vardır; o da hepsinin kutsalla temasa geçmeyi sağlayacak bir özelliğinin olmasıdır (Eliade M. , 2003).

Eliade'nin hemen hemen bütün eserlerinde onun metodolojisinin üç unsurunu görmekteyiz (Eliade M. , 2017):

(i) Kutsal ve dindış1/profan anlayış1

(ii) Sembolizm ve mit anlayışı

(iii)Sembol ve mitler aracılığı ile kutsalı bugüne taşıma 
Onun tanımlamalarından biri olan "mutlak yenilenme" yani zamanın döngüsel olduğuna olan inanç, ebedi dönüş, evrenin ve insanoğlunun dönem dönem yok olması, yeni bir evrenin yeni bir insanlığın "yeniden canlanması" inancı, akan zamanın, tarihin yenilenmesi umudunu ve arzusunu ortaya koyan bir unsurdur (Eliade M. , 2003). İlerleyen sayfalarda ele alacağımız kandilleri kutlama gerekçesi olarak ortaya çıkan ampirik bulgularda da aynı olgu, kutsal bir tarihi unsuru bugüne taşıma ve o anı yeniden yaşama olgusu vardır. Eliade'nin Yunan-Doğu terminolojisinden esinlenerek ele aldığı bu tanımlama tüm mitlerde ve öğretilerde karşımıza çıkan zamanın mutlak olarak yenilenmesi umudunu içinde taşır.

Her ne kadar aralarında ciddi farklıklar olsa da tabiat üstünün duygusal kategorisi olarak kutsalın, tanrı tasavvurlarının kaynağına atıfla tanımlandığı görülmektedir. Hemen hemen bütün tanımlar kutsalı; dinlerin kaynağını açıklamada birer anahtar kavram olarak ele almışlardır. Eliade ve Otto'nun yaklaşımları kutsalı dini fenomonojik bir bakışla inceleyen yaklaşımlar olması hasebiyle, kutsalın sırf psikolojik izahına bir tepki olarak onun indirgenemez kaynağını bulmak için yeniden ele almışlardır (Yapıcı, 2004). Bu bağlamda Eliade Otto'nun "Din kutsalın tecrübesidir." Şeklindeki tanımını kabul ederek, Durkheim'in "kutsal" ve "dindışı" ayrımından hareketle kendi düşünce sistemini inşa etmiştir.

Kutsalın; irrasyonel, esrarengiz, cezbedici, hayranlık uyandırıcı, ürkütücü, müphem ve karmış bir yapıya sahip olduğu düşünüldüğünde bireyler üzerinde bıraktığı etki ve izlenip de farklılık arz etmektedir. Hangi tanıma bakılırsa bakılsın, kutsalın beşerî açıdan tabiatta saf olarak görmek mümkün değildir. Çünkü, kutsal belli tarihî şartlarda, belirli bir toplum içerisinde ve sosyokültürel ortamda onu kendi zihinsel kapasitesi ile algilayan bireyin tasavvurundaki sübjektif özelliklere dayalı olarak ortaya çıkmaktadır (Yapıcı, 2004). Dolayısıyla kutsala dair her tanım içinde bulunulan toplumsal gerçekliğe bağlı olarak farklı şekillerde tezahür edebilmektedir. Buna göre dini âyin, dinî duygu, dinî düşünce, dinî tecrübe ve bizim konumuz olan "dinî geceler"in dayanak noktasını oluşturan kutsal; gerek Eliade'nin tanımlamasında yer alan "kutsal-profan" ayrımında, gerek diğer fenomonolojik yaklaşımların anlaşılmasında geniş bir alanı kapsayacak bir şekilde ele alınmaktadır. Kavrama dair ortaya konan bütün yaklaşım ve analizler ancak bir yorumlamadan öteye gidemeyecektir. Vergot'un da ifade ettiği gibi; "kutsal, birtakım müphemlikleri ihtiva eden ve oldukça yanlış anlaşılan bir kavramdır” (Vergote, 2002).

\section{Mevlid Fenomeni}

Hz. Muhammed'in doğumuna işaret ettiği manası ile rağbet kazanmış bulunan "mevlid" kelimesi Türkçe ve Arapça'da zamanla Hz. Peygamber' in doğum yıldönümünde yapılan merasim, tören ve kutlamaları ifade eder (Pekolcay, 2004). Müslümanlar arasında Hz. Peygamber'in dünyaya geldiği geceyi ifade eden "Mevlid Gecesi”ne diğer kutsal atfedilen (Kadir, Mirâc, Arefe, Cuma, Ragaib, Berat) gecelerden daha fazla önem verilmiş̧ir. Bu gecenin Müslümanlar arasında Kur'an'da ifade edilen bin aydan hayırlı olan, Kur'an'ın iniş gecesi olarak ifade edilen Kadir Gecesi'nden daha fazla önem bulması ise ayrı bir tartışma konusudur.

Mevlid, İslam edebiyatında Hz. Peygamber'in doğum yıl dönümünde yapılan tören ve etkinliklere verilen bir isimdir. Mevlid aynı zamanda bu törenlerde okunmak üzere yazılmış eserlerin ortak adıdır. Bu eserlerin içinde Süleyman Çelebi'nin Vesiletü'n-Necât 812 (1409) adlı eseri Bursa'da tamamlanmış olup yazılmış eserler arasında en meşhur olanıdır. Eser, özellikle Osmanlı coğrafyasında Hz. Peygamber'in doğum günlerinde okunarak, bestelenerek ve çeşitli dillere çevrilerek birçok alanda ün kazanmıştır (Özel, 2004).

Mevlid'in Hz. Peygamber'in sağlığında kutlandığına dair herhangi bir rivayet olmadığı gibi Hulafe-yi Râşidin ve Emevi, Abbâsî dönemlerinde de herhangi bir uygulamaya rastlanmamaktadır. Resmi olarak Mısır'da Şii Fâtımî Devleti kurulunca, soyundan geldiklerini söyledikleri Hz. Peygamber'in doğum yıl dönümü Muiz-Lidînillah döneminden (972-975) itibaren resmi olarak kutlanmaya başlanmıştır. Fatımiler döneminde Hz. Peygamber'in ve Ehl-i Beyt'in doğum 
yıldönümlerinin kutlandığına dair rivayetlerde bu kutlamaların halkın geniş bir teveccüh duyduğu dini bir hassasiyet olarak yapıldığını, üst düzey görevlilerin de bu törenlere iştirak ettiğini ve bu kutlamaların devlet eliyle meşruiyet kazandığını görüyoruz (Özel, 2004). Ancak sonraki dönemlerde yasaklanacak olan kandil gecelerinin Mısır'da Fatımiler eliyle kutlanış amacı halkın katılımıyla kutlanan bir bayram havasından ziyade devlet ileri gelenlerinin kendi aralarında kutladığı bir törene dönüşmüştür (Zeydan, 2016).

Mevlid kutlamalarını günümüzde kazandığı anlam ile merasim ve törene çeviren ilk hükümdar Muzafferüddin Gökböri'dir. Bugünkü manası ile bu dönemde başlatılan kutlamalar İslam dünyası içerisinde yaygınlık kazanmıştır (Banarlı, 1978). 1910 yılı itibariyle Osmanlı'da Mevlid geleneğinin bir devlet törenine dönüşmesi 1589 yılında Osmanlı Hükümdarı III. Murad, (1546-1594) döneminde başladığı ifade edilmektedir (Özel, 2004). Fakat bundan önceki dönemlerde de kutlandığına dair bilgiler mevcuttur. Bir başka rivayete göre Süleyman Çelebi'nin mevlidinin yazılma tarihi olan 812 (1409-1410)'dan sonraki dönemlerde başlamıştır (Toygar, 1982). Genel görüşe göre bu törenler Kanuni Sultan Süleyman dönemi ile birlikte saray protokolünde yer almıştır. III. Murad'ın Hz. Peygamber'in doğum yıl dönümü sebebiyle bütün minarelerde kandil yakılmasını ve camilerde mevlid okunmasını emrettiğine dair rivayetlerde yer almaktadır (Özel, 2004). Hemen hemen her devlet adamının katılımıyla gerçekleşen mevlid törenleri, büyük camilerde şaşalı törenler eşliğinde yapılmış, pahalı hediyelerin dağıtıldığı, görkemli sofraların kurulduğu bir bayram havas olarak kutlanmıştır. Böylelikle 1910 itibari ile resmi kanunla kabul edilen mevlid geleneği, Cumhuriyet tarihine kadar devam etmiştir.

Mevlid aynı zamanda insanların doğum, ölüm yıldönümlerinde veya o günlerin kendisinde, hacc ibadetinden veya askerden dönenlere, sünnet, düğün, nişan hatta örf ve geleneklerde yer alan her türlü merasimde özellikle Süleyman Çelebi'nin "Vesiletu'n-Necat" adlı manzumesinin makamlı olarak okunmasıdır (Parmaksızoğlu, 1976). Günümüze kadar gelen tarihi süreç içerisinde farklılaşmalar yaşansa da genel hatlarıyla mevlid kutlamalarının kaside, ezgi, ilâhi ve musikiler eşliğinde kutlandığını söyleyebiliriz.

Günümüzde Mevlid geleneği Kuzey Afrika'dan Endonezya'ya kadar İslam ülkelerinin bazılarında resmi, bazılarında ise gayri resmi olarak kutlanmaktadır (Özel, 2004). Türkiye'de ise Mevlid gecesi kandil geleneği içerisindeki ibadet adabı olarak cami, vakıf, dernek ve belediyelerin kültür sanat etkinlikleri adı altında her yıl mevlidhanlar eşliğinde kutlanmaktadır. Bu gecelerde Kur'ân-1 Kerîm, Süleyman Çelebi'nin mevlidi, ilâhi, kaside ve şiirler okunmaktadır.

\section{Kutsal Zaman Anlayışı}

Tarih boyunca farklı bölge ve kültürlerde kutsala yüklenilen anlam, kutsalın tezahür ettiği an üzerinden tanımlanmıştır. Bu anın kutsallığını devam ettirme isteği "kutsal zaman" kavramını ortaya çıkarmıştır. Bütün toplumlarda sıradışı bir zaman dilimi üzerinden tanımlanan kutsal zaman, sahip olunan inanışa, kültüre ve bölgeye göre değiş̧iklik göstermektedir. Yahudilikte önemli dönüm noktalarını ifade eden pek çok kutsal zaman dilimi vardır. Günümüzde kullanılan Yahudi takviminden yer alan kutsal zamanlar, Yahudiler açısından anlam ve önemi itibari ile birbirinden farklılık göstermektedir. Hristiyanların dini bayramlarının tamamına yakını İsa'nın yaşamıyla doğrudan ilişkilidir. Yılın çeşitli zamanlarında kutlanan Noel, Paskalya, Pentakost gibi anılan bu kutsal günler çoğunlukla farklı Hıristiyan mezheplerine göre değişen bir içeriğe sahiptir. Hindu dini takvimi günlük, haftalık, aylık, yıllık veya daha uzun zaman dilimlerinde yapılan pek çok dinsel törene sahiptir. Hindu mitolojisinde geçen meşhur olaylara, ayın evreleri, güneş ve ay tutulmaları ile ilgili sayısız kutsal gün yer almaktadır. Budist gelenekte inancın ortaya çıktığı ilk dönemlerde kabul edilmiş bir dini takvim yoktur. Budizm'in yayılması ile birlikte doğup gelişmiş bir takım kutsal günler ortaya çıkmış, zamanla dinî bir takvime dönüşmüştür.

İslamiyet'e baktığımızda ise yıl içerisinde yer alan günlerin dinî açıdan birbirleri ile aynı değerde olmadıkları görülmektedir. İslâm literatüründe "mukaddes" ya da "mübarek" kavramlarıyla 
ifade edilen zaman dilimleri, kutsiyetlerini Kur'an ve hadislere dayandırılarak açıklanmıştır. (Tekin, 2016). Dolayısıyla İslam dünyası tarafindan kullanılan hicri takvim, Kur'an'da yer alan ayet ve hadisler üzerinden oluşturulmuştur. İslam'da "kutsal geceler" olarak kabul edilen gecelerin büyük bir kısmı, İslâmi gelenekte kutsal kabul edilen aylara ait Recep, Şaban ve Ramazan aylarından oluşan "üç aylar" içinde yer almaktadır. Regaib, Miraç, Berat ve Kadir gecelerinin üç aylar içerisinde yer alması bu aylara verilen önemi arttırmaktadır. Buna göre söz konusu geceler, birer arınma gecesi, ferdi ve cemaatle icra edilen birer dini ritüele dönüşmüştür.

\section{Ritüelistik Din}

"Mit" ve "ritüel"in birbiri ile ilişkili olarak işlev görmesi din üzerine yürütülen çalışmaların önemini anlamak açısından üzerinde durulması gereken kavramlardır. Ritüelin işlevsel boyutu dini pratikleri ve inanç unsurlarını birlikte değerlendirerek inancı pratiğe yol açan bir unsur olarak değil pratiğin bir parçası olarak ele alır. Durkheim'in ifadesi ile bir topluluğa ait mitoloji, o toplumdaki yaygın inanışlar sistemini oluşturur. $\mathrm{Bu}$ anlamda dinsel törenler, ileriye dönük olarak unutulma ihtimallerini içinde barındırdığı için inançların varlığını sürdürmesine öncülük ederler. Durkheim'in ritüeli inanca bağlı bir unsur olarak görmesi onun mitlerin ritüellerden bağımsız olarak var olduğunu düşünmesine yol açar. Onun da ifade ettiği gibi "mit çoğunlukla dinsel törenden sonra biçimlenir..." (Durkheim, 1965).

Eliade'nin "efsaneleri yeniden güncelleştirmek" başlıklı tezinde, dindar insanların insanaşırı, aşkın bir modeli olan bir insanlığı üstlendiklerine işaret edilir. Bu tip insanların görüşünde, bireyin kendini gerçekten insan olarak tanımlayabilmesi için ancak tanrıları, medenileştirici kahramanları veya efsanevi ataları taklid etmesi gerekmektedir. Yani dindar insan kendinin dindış1 deneyinin düzleminde var olanından "başka" olmasını istemektedir. Bu modeller efsaneler ile tanrısal gesta öyküleri tarafından muhafaza edilmiş, bunun sonucunda ise dindar insan, tıpkı dindış1 insan gibi tarih tarafından yapıldığını kabul etmektedir, fakat kendisini ilgilendiren yegâne tarih, efsaneler tarafından ifşa edilen ve tanrılara ait olan "Kutsal Tarih" anlayışıdır (Eliade M. , 2017).

Eliade'ye göre dinsel bayram, bir olayın aktörlerinin tanrılar veya yar1-tanrısal varlıklar olduğu "kutsal" bir tarihin yeniden güncelleştirilmesidir. Buna göre "kutsal tarih" efsanelerde anlatılmaktadır. Bayrama katılanlar Tanrıların ve yarı-tanrısal varlıkların çağdaşları haline gelmekte, Tanrıların varlığı ve faaliyetleri ile kutsallaştırılmış zamanda yaşamaktadırlar (Ağaoğlu, 2009). Efsanelerin ve mitolojilerin Musevilik öncesi dinlerdeki önemi de buradan kaynaklanmaktadır. Çünkü efsaneler Tanrıların gesta'sını anlatmaktadır ve gesta tüm insanî faaliyetlerin örnek alınacak modellerini oluşturmaktadır. Dindar insan tanrılarını taklid ettiği ölçüde efsanevi zamanda yaşamaktadır. Sonuç olarak tanrısal örnek rol modellerinin taklidi hem onun kutsallık arzusunu hem de ontolojik özlemini ifade etmektedir (Eliade M. , 1995).

Dindar insana göre, aynı efsanevi olayların yeniden güncelleştirilmesi onun en büyük umudunun yenilenmesini ortaya çıkarmaktadır. Her yeni umut varoluşunu değiştirmekte, onu tanrısal modele benzer hale getirmektedir. Bu durum ise örnekleri efsanenin konusu olmaktan kurtaramamış, insanüstüleştirilen peygamber modelinin hayattan dışlanmasına sebep olmuştur.

Durkheim'e göre ritüellere mitten çok daha önemli bir yerde durur. Onun ifadesinde dinin merkezinde tanrıya yönelik inanç değil tanrıyı deneyimleme vardır. Bu deneyim toplumun bireylerinin ritüeli gerçekleştirmek için bir araya gelmesi ile ortaya çıkar (Durkheim, 1965). Ona göre mitoloji dini hayatın asli unsurudur. Eğer mit, dinden çekip çıkarılacaksa, ayinin çıkarılması da zorunlu hale gelir. Zira ayinler genel olarak bir isme, karaktere, belli sıfatlara ve bir tarihe sahip olan muayyen şahsiyetlere atfedilir ve söz konusu şahsiyetlerin tasavvurlarına uygun olarak değişirler (Durkheim, 2005).

Ritüellerin ya da dini törenlerin toplumsal birliktelikleri tek bir his etrafinda toplayarak harekete geçirmeyi, dayanışma ve topluma bağllık gibi duyguları tetiklediğini ve desteklediğini 
söyleyebiliriz. Yine ritüeller özellikle toplum üzerinde etkisi olan olumlu veya olumsuz bir toplumsal değer olan fenomenlere dair sevgi veya nefret duygusunu tetikler. Malinowski'ye göre ritüel, bireyleri etkileyen bir fenomene karşı harekete geçirir. Toplumsal dini duyguların tatmini için bir ara kablosu görevi gören ritüellerin özellikle toplum tarafından kutsal kabul edilip geri dönüşü mümkün olmayan olayların bir fenomenle temellendirilerek yeniden hayat bulmasının bir tezahürüdür. Diğer bir ifadeyle kutsalın yeniden üretilmesi ve bireylerin dini duygularının tatmini için bir işlevsel zemin oluşturma görevindedir.

\section{Kutlama ve Dini Sembollerin Metalaşması}

Tüketim kavramını ekonomik anlamda ele aldığımızda tüketme ve yararcılık olarak ifade bulmasının yanısıra dışavurum, gösteriş, sembol, imaj ve işaretlerin de anlam bulduğu sosyal ve kültürel bir olgu olarak tanımlanmaktadır (Baudrillard, 1997). Tüketim kavramı Baudrillard'ın ifadesi ile nesnelerin tüketiminin yanı sıra, bireylerin fikirlerinin ve görüngülerinin de tüketilmesini ifade eder. Tüketilen ürünler taşıdıkları sembol anlamlarından ötürü bireylerin kimliklerine dair aidiyetler de taşır. Baudrillard'ın Tüketim toplumu (1997) eserindeki ifadesine göre nesneler sayılarıyla, yinelenmeleriyle, gereksizlikleriyle, biçimlerinin aşırı bolluğuyla, kendilerindeki saf ve basit işlev sınırını aşan her şeyle yalnızca toplumsal özü (statü) yani bazılarına sadece doğumla verilen ve diğerlerinin tersine bir yazgı yüzünden hiçbir zaman ulaşamayacakları bir Tanrı lütfunu temsil eder (Baudrillard, 1997). Bu ifadeye göre mirasla -kan bağ1- veya kültürel bir gelenek olarak elde edilen bu meşruluk statü kavramını temellendirmiştir. Statü, toplumda yükselmenin tüm dinamiğine rehberlik eder. Tüm özlemlerin kökeninde bu doğumdan gelen statü, lütuf ve mükemmellik statüsüne duyulan ideal amaç yatar.

Alt ve orta sinıflardaki nesne yoluyla kanıtlamaya dayalı tüketim olgusu, "kutsallık" atfedilerek satın alınan eşyalara yüklenen anlamda kendini bulur. Tüketim yoluyla kurtuluşa ereceğini, ahlaki arınmayı bu yolla sağlayacağını düşünen bir aklın eşya-insan ilişkisindeki nesneleştirme süreci de Baudrillard'ın ifadesiyle, "büyülü bir iktidar kaynă̆ı" sağlamakta, bireylerin dini duygularını tatmin etme yolunu meta unsura taşıyarak kısa süreli de olsa bir arınmışlık hazzı sağlamaktadır.

Metalaşma süreci, bireylerin istifadesini sunulmuş her unsurun meşrulaştırılarak onun hakiki değerinden meta değere indirgenmesi ile oluşmaktadır. Tüketim yalnızca kapitalist değerlerin hâkim olduğu daha fazla kazanmaya endeksli toplumların ortaya çıkardığı bir kültürel süreç değildir. Bu ekonomik döngünün içerisine, soyut değerlerin tüketim alanına indirgenerek İslami pratik ve öğretilerin birer meta unsuru haline dönüştürülmesi de dahil edilebilir. Dini unsurların meta değerleri onların fiyat merkezli bir endüstriyel nesne haline gelmesi ile değil o şeyin misyonunun buharlaşması, hakiki değerinden edilmesi, saf ve samimi duygular aracılığı ile özne konumundan nesne konumuna indirgenmesi ile de gerçekleşebilir. Dolayısıyla ekonomik ve toplumsal yaşamın birçok alanında vitrinde yaşanan bir din olgusu dini duyguların bir arza, bu arzın da bir talep oluşturması ile ortaya çıkan İslami Pazar unsurlarının kapitalizm ile içkin konuma gelmesine sebep olmuştur. İslami pazarda satışa çıkan bu ürünler kimi zaman "kandil simidi”, "lokum", "seccade", "tesbih", "kokulu Yasin-i Şerif" olarak kimi zaman da mevlidhan ekiplerinin dahil olduğu kutlama, tören, salon programları aracılığı ile kendini göstermektedir.

Tüketim ve dinin iç içe geçmiş olarak ortaya çıkan bu etkileşimi Müslüman toplumların tüketim tercihlerinin de dini çerçevede ele alınmasına ve bunun piyasa değeri olarak ortaya çıkmasına neden olmuştur. Kutsal ile olan ilişkisini daha steril hale getirmek için dini günlerde yapılan harcamaların israf olmayacağını düşünen bir zihnin sömürüye açık olması ve tamamen safiyane niyetlerle yapılan bu dini ritüelin kurumsal bir faaliyete evirilerek tüketim toplumu için bir sömürü unsuruna dönüşmesi kaçınılmazdır.

Bu manada mevlid kutlamalarının toplumsal bileşenlerini ortaya koyacağımız bu çalışmada Hz. Peygamber'i anlama noktasında istikamet açısını doğru tespit edebilmek için bireylerin kutsal- 
profan, makul-mahsus, logos-mitos, gelenek-ritüel, gerçek-efsane gibi kavramlara yükledikleri anlamları açık ve anlaşılır bir şekilde ortaya koymak gerekmektedir. Gerçeğin ortaya koyduğu peygamber tasavvuru ile kurgusal olarak mitolojik bir kahramana dönüştürülen peygamber algısı, ortaya geniş çaplı bir mevlid edebiyatı çıkarmıştır. Mevlid kutlamaları aracılığı ile her geçen yıl genişleyen bu Mevlid-i Nebi müktesebatının anlam değerinden uzaklaştırılarak kutsal ve dokunulmaz bir değer olarak toplumun her kesiminden grupları arasında meşruiyet kazanması, Müslüman toplumların kutsal ile olan bağını anlamak açısından oldukça önemlidir.

Tüm bu boyutları farklı eksenler üzerinden değerlendirmeye alacağımız bu çalışmada bireylerin kutsal, tüketim ve din etkileşimi; gelir, yaş, eğitim, cinsiyet, kentlilik gibi bağımsız değişkenler üzerinden "Mevlid Kandil" geleneği ve "Kutlu Doğum Haftası" etkinliklerine yüklediği anlamlar açısından incelenecektir.

\section{Araştırmanın Amacı ve Problemi}

Bu çalışmanın amacı; Sabahattin Zaim Üniversitesi'nde okuyan öğrencilerin dini bir ritüel olarak Kandil gecelerini kutlayıp kutlamadıkları ve özelde Mevlid Kandili ve Kutlu Doğum Haftası etkinliklerine dair görüş ve ritüellerini öğrenmektir. Bu amaca yönelik şu alt problemlere dair çözüm ve cevaplar da aranmıştır.

1. Yüksek öğrenim gören öğrencilerin “kutsal”a yüklediği anlam günümüzdeki dinî/ilâhî manası ve muhtevası üzerinden mi anlaşılmaktadır yoksa dinî anlamdan uzaklaşarak tamamen kültürel bir fenomen olarak mı algılanmaktadır?

2. Türkiye'de yaşayan Müslümanların kutsala dair inanışlarını oluşturan unsurlar nelerdir? Bu unsurlar gelenek ile mi yoksa ilahi bir öğreti ile mi belirlenmektedir?

3. Türkiye'deki üniversitelerde okuyan öğrencilerin, üniversite hayatı ile birlikte Kandil gecelerine olan inanışlarında ve ritüellerinde bir değişiklik oluşmuş mudur?

4. Türkiye'deki üniversitelerde okuyan öğrencilerin Mevlid Kandili sebebi ile Kutlu Doğum Etkinlikleri çerçevesinde yapılan programlara karşı tutumları nelerdir?

5. Etkinlik olarak yapılan bu kutlamaların Hz. Peygamber özelinde dini unsurları metalaştırdığını ve amacından uzaklaştırdığını düşünüyorlar mı?

\section{Yöntem}

\subsection{Araştırma Deseni}

$\mathrm{Bu}$ araştırmada olaylar ve olgular doğal ortamlarında betimleme yapılarak, katılımcıların görüşleri ve bakış açılarını anlamaya yönelik nitel araştırma yöntemi kullanılmıştır. Nitel araştırmalar psikolojik ölçümler ve sosyal olaylarla ilgili nicel araştırma yöntemlerine göre daha derinlemesine bilgi sağlarlar. Nitel araştırmalar, geleneksek araştırma yöntemleriyle ifade edilmesi zor olan sorulara cevap bulmak için gereklidir (Büyüköztürk, vd., 2016). Nitel araştırmada araştırmacı, yoğun bir dikkat, empatik kavrayış, tartışılan mesele hakkındaki önceden sahip olunan kavrayışların ertelenmesi veya 'paranteze alınması'nı gerektiren bir işlemle yerel aktörlerin kavrayışlarına, 'içerden bakış’a dayanan verileri yakalamaya çalışır (Punch, 2016). Araştırmada ortaya çıkan nitel veriler görüşme tekniği ile elde edilmiştir. Görüşme, insanların gerçeğe ilişkin algılarına, anlamlarına, tanımlamalarına ve gerçeği inşa ediş̧lerine vakıf olmanın iyi bir yoludur (Punch, 2016). Görüşmenin temelinde sorulan soruya yanıt alma amacı vardır. Görüşmeler, kaynakların ulaşılabilirliğine ve araştırmada toplanmak istenen verilerin özelliklerine göre farklı şekiller alabilirler. $\mathrm{Bu}$ araştırmanın yöntemini nitel bir araştırma modelinde kullanılan dört yöntemden biri olan "odak grup görüşmesi" oluşturmaktadır. Odak grup görüşmesi ortak bir sorun etrafında birleşebilen grup üyelerinin, görüşmecinin soracağ 1 sorulara, karşıllklı etkileşimde bulunarak cevap aramaları ile meydana gelir. Gruptaki her üye, kendi görüşlerini belirtirken, öteki 
üyelerin görüşlerini de öğrenir. Üyeler, genellikle konuyu birbirleri ile tartışırlar; görüşmeci, bu tartışmaları başlatmak, amaçtan uzaklaşmamasını sağlamak ve ortaya çıkan bilgileri toplamakla görevlidir (Karasar, 2014). Odak grup görüşme yöntemi daha çok pazarlama alanlarında müşteri memnuniyetini ölçmek veya yükseköğretim kurumlarında öğrenci beklentilerini öğrenmek için kullanılır (Karasar, 2014).

Çalışmada ele alınan konu bağlamında odak grup görüşme yönteminin tercih edilmesinin başlıca sebebi, bir olayı meydana getiren ayrıntıları daha yakından görmek ve farklı bakış açıları etrafında incelemektir. Araştırma kapsamında yapılan görüşmeler araştırmacının sormayı planladığı soruları önceden hazırlayarak bir moderatör eşliğinde görüşme esnasında grup üyelerine yöneltmesi ile gerçekleşir. Görüşmelerde ilgili alanda derinlemesine gidebilmek için görüşmenin akışına göre alt soru başlıkları oluşturulabilir ve muhataplara açık uçlu sondaj sorular yöneltilebilir.

\subsection{Araştırma Örneklemi}

Araştırmaya İstanbul Sebahattin Zaim Üniversitesi'nin farklı bölümlerde öğrenim gören 13 öğrenci katılmıştır. Araştırmada her biri 6-8 arası katılımcıdan oluşan iki ayrı odak grup görüşmesi yapılmıştır. İlk odak grup görüşmesi farklı bölümlerde okuyan 7 lisans öğrencisinden oluşurken ikinci grup İstanbul Sabahattin Zaim Üniversitesi Sosyal Bilimler Enstitüsü Sosyoloji Yüksek Lisans bölümünde okuyan 6 öğrenciden oluşmaktadır. Araştırmaya katılanların 7'si kız, 6'sı erkek öğrencidir. Yaş gruplarına göre dağılımı ise on kişi (15-30), üç kişi ise (31-45) yaş aralığında yer almaktadır. Görüşmeye katılan öğrencilerin dördü evli, dokuzu ise bekardır. Öğrencilerin tamamına yakını büyük şehirde yaşamaktadır. Katılımcıların mezun oldukları veya okumakta oldukları lisans eğitimleri ise şöyledir; İlahiyat (2), Sosyoloji (7), Siyaset Bilimi ve Kamu Yönetimi (1), Eğitim Fakültesi (1), Endüstri Mühendisliği (1), Rehberlik ve Psikolojik Danışmanlık (1). Katılımcıların ailevi ve bireysel ekonomik göstergeleri ise iyi ve orta arasında farkl1lık göstermektedir. Tablolarda yer alan 13 katılımcının isimleri "K1" (Katılımc1 1), "K2" (Katılımc1 2) olarak numaralandırılarak verilmiştir.

\subsection{Verilerin Toplanması ve Çözümlenmesi}

Araştırmada katılımcılardan odak grup görüşmesi aracılı̆̆ 1 ile veri toplanmıştır. Verilerin toplanma aşamasında ses kayıt cihazı kullanılmış olup aynı zamanda yardımcı röportör desteği ile yazılı olarak kayıt altına alınmıştır. Görüşmeler katılımcıların bilgisi dahilinde kayda alınarak her odak grup görüşmesi yaklaşık olarak 60 dakika sürmüştür. Açık uçlu soruların yöneltilmesi ile yapılan görüşmelerde 9 adet soru kullanılmıştır. Soruların katılımcılar tarafından kolay anlaşılabilir ve günlük konuşma dilinde olmasına, açık uçlu olmasına ve yönlendirme içermemesine özen gösterilmiştir. Araştırmacı tarafından oluşturulan soruların geçerlilik ve güvenirlilik çalışmaları kapsamında iki öğrenci ile pilot görüşme yapılarak anlaş1lırlığ test edilmiştir. Anlaşılmayı güçlendiren sorular yeniden gözden geçirilmiş ve gerekli düzenlemeler yapılarak gerektiği kısımlara sondaj sorular eklenmiştir. Görüşmede yöneltilen sorular belirli bir tema etrafında hazırlanmış olup, bireylerin konu ile ilgili tutum ve davranışlarını ortaya çıkartan sorular tartışmaya açılmıştır.

Elde edilen veriler katılımcıların vermiş olduğu cevaplar çerçevesinde çözümlenmiştir. Araştırma bulguları oluşturulurken yoruma açık sorulara verilmiş yanıtlar doğrudan aktarılarak tablolaştırılmıştır. Diğer bir kısım sorular ise yorumlama ve gözlem notları ile ifade edilmiştir.

\section{Bulgular}

Araştırma sonucu elde edilen bulgular kullanılabilir hale getirilerek tablolaştırılmıştır. Tabloda kullanılan verilerin sıralanışında lisans öğrencilerinden başlayıp yüksek lisans öğrencilerine doğru bir dizilim uygulanmıştır. Lisans okuyan öğrencilerin isimlerinin altına okudukları dereceyi belirtmek için "L" işareti, yüksek lisans okuyan öğrencilerine ise "YL" işareti eklenmiştir. 


\section{1. "Kutsal"In Tanımları}

Dini düşüncenin ayırt edici bir özelliği olan kutsal; inançları, mit, doğma ve efsaneleri, kutsal olana atfedilen fazilet ve güçleri, dini tutum ve davranışları açıklamada bir anahtar kavram niteliğindedir. Bireylerin 'kutsal'a dair duygu ve düşünceleri onların dini tutum ve davranışlarındaki bilinçlilik durumunu da ortaya çıkarır. Dolayısıyla kutsal-din ilişkisi dinin tanımlanması konusunda belirleyici bir etkendir. Günümüzde kutsalın anlamı bireylerin içinde doğduğu dini yaşayış ve algılanış şekline göre değişmektedir. Asıl anlamı olağanüstü değerlere sahip olan bir sıra dışıllı̆ı, irrasyonel ve esrarengiz olanı ifade etse günümüz çağdaş yorumları ile birlikte mistik ve esrarengiz alana dair duygu ve düşüncelerin bütün aşamalarını yani "kutsalın tecrübesi"ni de ifade etmektedir (Eliade M. , 2017).

Araştırmanın amacına dair alt problemlerin birincisi olan Türkiye'de yaşayan Müslümanların kutsala dair inanışlarını oluşturan unsurların neler olduğu ve bu unsurların gelenek ile mi yoksa ilahi bir öğreti ile mi belirlenmekte olduğu sorusu, araştırmanın bulgularında yer alan Tablo 1'deki cevaplarla örtüşmektedir. Katılımcıların kutsala dair tanımlamalar yaparken, edindikleri dini bilgi ve birikimlerinden yola çıkarak bir açıklama yaptıkları, daha önce üzerinde düşünme ihtiyacı duyulmayan, onu dokunulmaz ve sorgulanamaz bir alan olarak kabul etmelerinden kaynaklanan bir takım ifade zorlukları ortaya çıkmaktadır. Bu süreçte din olgusunu anlamada "kutsalın tecrübesi" ifadesi anahtar kavram olarak ele alınmıştır. Buna göre kutsal ile ilâhî olanın birbirine benzer kavramlar olduğu görülmekte, dinî olan ile kutsal olan birbirinin yerine kullanılagelen iki kavram olarak anlaşılmıştır (Yapıcı, 2004). Buna göre kavramsal çerçevede ele alınan," ritüelistik din" başlığı, Durkhemin'in de ifadesi ile toplumsal bir gruba ait öğretilerin o toplumdaki yaygın inanışlar sistemine dönüşmesi ile ortaya çıkmaktadır. Bu anlamda sosyokültürel yaşamın ayrılmaz bir parçası olarak ele alınan ritüeller, kolektif bir alan inşa ederek sosyal bütünleşmenin önemli bileşenlerinden kabul edilmektedir. $\mathrm{Bu}$ düşüncelerden yola çıkarak katılımcıların 'kutsal'ın tanımına ilişkin düşünceleri, din ile kutsal arasındaki ilişkiye dair görüşleri, İslam dininde kutsal ve dokunulmaz atfedilen mitolojik unsurların olup olmadığ 1 ve kutsal ile hoşgörü arasındaki ilişki öğrenilmeye çalışılmıştır.

Tablo 1: Katılımcıların Kutsalın Tanımına ve Din ile Kutsal Arasında Bir İlişkinin Olup Olmadığına Dair Görüşleri:

\begin{tabular}{|c|c|}
\hline $\begin{array}{l}\mathrm{K} 1 \\
(\mathrm{~L})\end{array}$ & $\begin{array}{l}\text { Kutsal, Tanrı tarafından anlam verilen, ulaşması güç olan bir değerdir. Kutsal deyince aklıma } \\
\text { diğer dinlerdeki kutsal algısı, katedraller falan geliyor. İslam'da kutsallığın referansı Kur'an'dır. } \\
\text { Allah'ın emirleri ve onun sözleri gibi. Hinduizm ve Budizm gibi dinlerde kutsallık bir kitapla } \\
\text { değil daha çok ritüeller ve mitlerle, toplumsal inanışlarla desteklenmiş bir kutsallık. Onların } \\
\text { referansı, hayali mitolojik kahramanlar, İslam dininin referansı ise Kuran'dır. }\end{array}$ \\
\hline $\begin{array}{l}\mathrm{K} 2 \\
(\mathrm{~L})\end{array}$ & $\begin{array}{l}\text { İnancımızda yüksek kabul ettiğimiz değerler. Dogmatik gibi görünse de dokunulmaz bir yanı } \\
\text { vardır. Kutsal ile din arasındaki ilişkiyi tamamen Allah tarafindan yaratılmış bir şeymiş gibi } \\
\text { algılayamayız. Din olarak sadece İslam’ı aldığımızda diğer dinlerin kutsalını yok sayarız. Her } \\
\text { dinin kendi kutsalı var. İnandıkları değerler onlara göre kutsaldır. İnek mesela Hindulara göre } \\
\text { kutsal atfedilen bir şeydir. }\end{array}$ \\
\hline $\begin{array}{l}\text { K3 } \\
\text { (L) }\end{array}$ & $\begin{array}{l}\text { İçinde saygıyı ve dogmatikliği barındıran bir kavramdır. Din, kutsallığın büyük bir çoğunluğunu } \\
\text { kapsar ancak insanlar din dışı motiflere ve simgelere de kutsallık atfedebilir. }\end{array}$ \\
\hline $\begin{array}{l}\text { K4 } \\
(\mathrm{L})\end{array}$ & $\begin{array}{l}\text { Kutsal, dini açıdan saygı duyulan ya da saygı unsuru olarak kabul edilendir. İnsanlar din ile } \\
\text { ilgili çoğu şeyi kutsal olarak kabul ediyorlar fakat kutsalı belirleme yetkisinin sadece Allah'a } \\
\text { ait olduğunu unutmamak gerekir. }\end{array}$ \\
\hline $\begin{array}{l}\text { K5 } \\
(\mathrm{L})\end{array}$ & $\begin{array}{l}\text { Kutsallaştırdığım şeyler vicdanıma dokunan, vicdanıma yön veren inandığım değerler. Dini } \\
\text { çerçeve içerisinde ise namazlar, aile gibi unsurlar da kutsaldır. Din ile kutsal arasındaki bağa } \\
\text { baktığımızda her dinin kutsalı vardır. Din olmasa bir toplum yaşayamaz. İslam dini için belki } \\
\text { böyle söyleyemem ama diğer dinler için kutsal olmasa o din yaşayamaz. }\end{array}$ \\
\hline & $\begin{array}{l}\text { Dokunulması, talep edilmesi bile önerilemeyecek şeylere kutsal deniyor. Halk nezdinde kutsal } \\
\text { daha çok Allah, kitap, peygamber, Kur'an gibi kavramlar. Benim için ise kutsal kavramı çok }\end{array}$ \\
\hline
\end{tabular}




\begin{tabular}{|c|c|}
\hline $\begin{array}{l}\text { K6 } \\
\text { (L) }\end{array}$ & $\begin{array}{l}\text { esnektir. Zamana, kişiye, olaya göre değişen bir şeydir ancak avam tabakaya baktığımızda bazı } \\
\text { kutsallar kutsaldan ziyade gelenek, tabu olarak algılanıyor. Kutsal yıkılabilen, zaman zaman } \\
\text { yıkılması gereken bir olgudur. Kutsal illa ki olacaktır. İnsan bazen korkmak bazen sığınmak } \\
\text { istiyor. Bunun için zaman zaman Tanrı'yı veya başka objeleri kullanabiliyor. Bazen de makamı } \\
\text { mevkiiyi kutsal atfedip kullanabiliyor. Din ile kutsal arasındaki kesinlikle bir bağ var. }\end{array}$ \\
\hline $\begin{array}{l}\text { K7 } \\
\text { (L) }\end{array}$ & $\begin{array}{l}\text { Bana göre kutsal daha manevi değerler. Her dinin kendisine ait olan tanrı ve insan arasında } \\
\text { onların inanmalarına sağlayan ve önem verdikleri düşünce, maddi varlık, nesne ve obje olabilir. } \\
\text { Din ile kutsal arasındaki ilişki insanın manevi tarafıdır. Din olmasa bile insanın inandığı değer } \\
\text { de din adını alabilir. }\end{array}$ \\
\hline $\begin{array}{c}\text { K8 } \\
(\mathrm{YL})\end{array}$ & $\begin{array}{l}\text { Doğuştan bize aktarılmış ve kabul etmemiz gereken bir şey. Sorgulanmaya çok açık olmayan. } \\
\text { Ben hiç sorgulamadım ve kabul ettim. Din ile kutsal arasında bir bağlantı var, kutsal deyince } \\
\text { benim aklıma direk din geliyor. }\end{array}$ \\
\hline $\begin{array}{c}\text { K9 } \\
\text { (YL) }\end{array}$ & $\begin{array}{l}\text { Toplum tarafindan insanların onlara değer atfetmesiyle toplumda değer verilen manevi ya da } \\
\text { maddi varlık. Genel bir kutsal toplumun verdiği ortak karar ile olur. Kutsal kişiden kişiye } \\
\text { toplumdan topluma değişir. Kutsallık başkası tarafından da verilebilir ancak ben onu kabul } \\
\text { etmem. Benim için kutsal ilahi olandır. }\end{array}$ \\
\hline $\begin{array}{l}\text { K10 } \\
\text { (YL) }\end{array}$ & $\begin{array}{l}\text { Dini inançlar kümesine giren kavramdır. Dokunulmaz ve değiştirilebilir olarak çift yönlüdür. } \\
\text { Örneğin "anne” kutsaldır ancak annenin kutsiyetini o şemaya biz ekleriz. Fakat Kuran'ın } \\
\text { kutsallığı sabittir. }\end{array}$ \\
\hline $\begin{array}{l}\text { K11 } \\
(\mathrm{YL})\end{array}$ & $\begin{array}{l}\text { Herkesin bir kutsalı vardır, bu inanç noktasında sevgi, saygı noktasında olabilir. Genel bir } \\
\text { kavram olduğunu düşünüyorum. Rabbimizi, gönderdiği Kitap, peygamber hepsi çok kutsaldır. } \\
\text { Daha özelde "anne" kavramı da benim için özeldir, kutsaldır. Bu daha çok çift boyutlu bir tanım. }\end{array}$ \\
\hline $\begin{array}{l}\text { K12 } \\
\text { (YL) }\end{array}$ & $\begin{array}{l}\text { Kutsal kavramını "aşkın güç" olarak tanımlayabilirim. İnsanlara verilmiş olan veya insanın } \\
\text { kendisinde de oluşturmuş olduğu sahip olduğu değerlerin üzerinde aşmış olan, aşkınlığa erişmiş } \\
\text { olan bir güç olarak değerlendiriyorum. Kutsal kavramı soyuttur. Ritüelleri belki } \\
\text { somutlaştırılabilir. }\end{array}$ \\
\hline $\begin{array}{l}\text { K13 } \\
\text { (YL) }\end{array}$ & $\begin{array}{l}\text { İki türkü kutsal var, birincisi kutsala inanç noktasında bir bakış kazandırıldığında elde edilen } \\
\text { kutsal, diğeri toplumsal yaşantı içerisinde insanların önem atfettiği kutsal. Biri ilahi, diğeri } \\
\text { toplum tarafından atfedilen bir kutsallık. Kutsallık ilahi ve insanların inançları bağlamında } \\
\text { bakıldığında yaradan tarafından belirlenen bir şeydir. Ancak insanların yaşayış biçimlerine } \\
\text { bunu yaydığımızda kendi kutsallarını oluşturduğunu düşünüyorum. Müslümanlar için Kur'an } \\
\text { ne kadar önemli ise Hristiyanlar için de kendi kitapları o kadar önemlidir. Kutsallık düşünceye } \\
\text { kadar indirgenebilir. }\end{array}$ \\
\hline
\end{tabular}

Tablo incelendiğinde katılımcıların tamamına yakınının ortak bir "kutsal" tanımının oluştuğunu görüyoruz. Verilen cevaplarda kutsalın daha çok Tanrı tarafından verilen, dokunulmaz, ulaş1lması güç, manevi bir yönü olan değerler bütünü olduğu ifade edilmiştir. Tabloya göre "kutsal" kavramı duyulduğu zaman ilk çağrışım yapan niteliklerden biri de "değerli" olan ifadesidir. Burada ifade edilen değer; dinî ya da seküler anlamda her türlü kıymeti içine alan çoğunlukla öznel (benim için değerli olan vb.), nadiren de nesnel (genelde değerli kabul edilen şeyler vb.) olarak anlamlandırılmıştır. Yapılan görüşmede K6 ve K9 kutsalı; dogmatik ve saygınlığı da içinde barındıran bir kavram olarak ifade etmiştir. Görüşmede katılımcıların çoğu kutsalı tanımlarken diğer dinlerdeki (Hristiyanlık, Hinduizm vb.) kutsal atfedilen unsurlara da değinerek her dinin kendi kutsalı olduğunu ve bu kutsala saygı duymak gerektiğini ifade etmişlerdir. Her dinin kendi kutsalını oluşturduğu bir dinde kutsal kabul edilen bir değerin diğer bir başka din için geçerli olmayacağ görüşü de belirtilen ortak kanaatlerdendir. "Kutsal" tanımının katılımcıların hemen hemen tamamına göre İslam dininde tabulaştırılmış bir inançlar kümesi olduğunu ve sorgulanmaya açık olmadığını ve bunun negatif bir yön olduğunu ifade eden görüşlerin yanısıra onun aşkın bir güç olduğunu ve sorgulanmaması gerektiğini belirten görüşler de vardır. Kutsal kavramının çağrıştırdığ1 ikinci bir mana ise Kur'an-1 Kerîm başta olmak üzere “kutsal kitaplar"dır. İslam dininin kutsallığının Kur'an ile sabit oluşunun diğer dinlerin kutsalına göre daha kolay kabul edilebilir bir yanı olduğu da ortak ifadelerden birisidir. Bunlar1 sıras1 ile "aile", "yüce", İslâm/din", "devlet, vatan, bayrak", "Hz. Muhammed", "kutsal mekân”, "kutsal gece”ler, "kültürel değerler” gibi çağrışımlar takip etmektedir. 
Kutsal ile din arasındaki ilişkiye verilen cevaplarda, "kutsal" ve "din" kavramları birbiri ile ilişkili kavramlar olarak görülmüş, dinden bağımsız bir kutsallık alanının oluşmayacağı ifade edilmiştir. Katılımcılardan K6 için "kutsal" kavramı; esnek, zamana ve kişiye, olaya göre değiş̧en bir olgudur. Avamın kutsalını ise şöyle ifade etmiştir; "avam tabakaya baktı̆̆ımızda bazı kutsallar kutsaldan ziyade gelenek, tabu olarak algllaniyor. Kutsal ylkılabilen, zaman zaman yılklmast gereken bir olgudur". Diğer bir katılımcı olan K11 ise "anne" kavramının kendisi için kutsal olduğunu ve kutsalın çift boyutlu bir tanım olduğunu ifade etmiştir. Görüşmeye katılan öğrencilerin vermiş olduğu cevaplardan yola çıkarak eğitim seviyelerine ve yaş gruplarına göre bir ayırım yaptığımızda lisans okuyan ve yaş grupları 15-30 arasındaki öğrencilerin yüksek lisans okuyan ve yaş grupları daha yüksek olan öğrencilere göre daha rasyonel cevaplar verdiği, kutsalı dogmatik bir çerçevede dokunulmayan bir alan olarak gördükleri gözlemlenmiştir. Burada M. Eliade'nin tanımından yola çıkacak olursak; kutsalın kendisini kutsal olmayandan daha farklı bir biçimde gösterdiğini ifade edebiliriz. Buna göre inanan bir kişinin belirli şeylere kutsallık atfetmesinin arka planında kutsalın kendisinden kaynaklanan bir değerden ziyade ilâhî olanın tezahürü ile o şeyin kutsallık kazandığı söylenebilir.

\subsection{Dini Bir Ritüel Olarak Kandil Geceleri}

İslamî gelenekte Mevlid, Regaib, Miraç, Berat ve Kadir Gecesi olmak üzere beş ayrı gece kutsal olarak kabul edilmekte ve bu geceler kandil geceleri olarak kutlanmaktadır. Osmanlı padişahı II. Selim döneminde (1566-1574) yapılan kutlamalarda, camilerin kandilleri aydınlatması geleneğine dayanmaktadır (Bozkurt, 2012). Mevlid Kandili Hz. Peygamber'in doğduğu, Miraç Kandili ise miraca yükseldiği günün anısına kutlanır. Müslümanlar tarafından kutlanan gecelerin en önemli olanı Kur'an'ın da Kadir sûresi (97) ile işaret ettiği Kadir Gecesi'dir. Kadir Gecesi diğer kutsal gecelerden farklı olarak bizzat Kur'an tarafindan işaret edilerek, o gecenin bin aydan daha hayırlı olduğu vurgulanmıştır.

Dini günler ve o günlerde gerçekleşen törenler dini hayatın tecrübe edilmesini sağlayan ögelerden birisidir. Dini törenler, kutsalın tecrübe edilebilme imkanını sunarlar. Sergilenen ritüeller, sembolik kalıpların günlük yaşam içerisindeki görünümleri, bireylerin norm ve sembollere yüklediği anlamlar, din ile kutsal bağının çözümlenmesine yardımcı olur. Durkheim'e göre karakteristik olarak dini fenomen, var olan ancak kökten bir biçimde bir diğerini dışlayan ve her şeyi kapsayan iki cins halinde ikili bir bölünmeyi kabul eden bir olgudur (Durkheim, 2005). Yani ayinler ve ritüeller bir kimsenin kutsal olan şeylere karşı nasıl davranılması gerektiğini emreden davranış kurallarıdır. Durkheim dini inançların ibadet ve tören olarak ikili bir ayrıma tabi tutulması gerektiği düşüncesindedir. Dolayısıyla kandil geceleri inancin irrasyonel boyutu ile duyusal bir tecrübeyi, rasyonel boyutu ile tören ve kutlamayı sembolize eder.

Araştırmanın amacına dair alt problemlerden ikinci olan Türkiye'deki üniversitelerde okuyan öğrencilerin, üniversite hayatı ile birlikte Kandil gecelerine olan inanışlarında ve ritüellerinde bir değişikliğin olup olmadığı sorusu Tablo 2, Tablo 3 ve Tablo 4'deki ifadelerde katılımcılar tarafından farklı bakış açıları ile gerekçelendirilmiştir. Kavramsal çerçevede ifade edilen Mevlid fenomeni, araştırmanın bulgularında toplumsal bir olgu olarak ele alınmasının yanısıra, bireylerin ona yükledikleri anlam ile de değer bulmaktadır. Kutsal olana dair geliştirilen her bir davranış kalıbı ritüelistik dinin sembolik ve törensel bir ifadesi olarak görülmektedir. Bu manada katılımcilara yöneltilen kandil gecelerinin kutlanması sorusunda, bir toplumsal davranış türü olan dini ritüeller, âyinler ve fiillerin hangi iç ve dış etkenler dahilinde kabul görüldüğünün öğrenilmesi hedeflenmektedir. 
Tablo 2: Katılımcıların Dini Bir Ritüel Olarak Kandil Gecelerini Kutlayıp Kutlamadıkları ve Neden Kutladıkları/Kutlamadıklarına Dair Görüşleri:

\begin{tabular}{|c|c|}
\hline $\begin{array}{l}\mathrm{K} 1 \\
(\mathrm{~L})\end{array}$ & $\begin{array}{l}\text { Çocukken kutlardık. Hatta lisedeyken de kutlardık. Önceden annem babam da kutlardı. 'Namazınız } \\
\text { kllın, bu gece çok dua edin' gibi ifadelerle bize de hatırlatırlardı. Şu an kutlamamamın sebebi; bu } \\
\text { gecelerin önemini araştırmam ve ikna olmamla alakalı. Bu araştırma sürecimde İslam'da yerinin } \\
\text { olmadığını gördüm. Kutlu doğumun efendimiz döneminde kutlanmadığını da okuyunca demek ki } \\
\text { Allah tarafindan referans alınan mübarek günlerden değil diye düşündüm. Biz bunu neden } \\
\text { yapıyoruz diye sorguladım ve gerek olmadığına karar verdim. }\end{array}$ \\
\hline $\begin{array}{l}\mathrm{K} 2 \\
(\mathrm{~L})\end{array}$ & $\begin{array}{l}\text { İstanbul'a geldiğimden beri kutlamadım. Yatsı namazından sonra belki Kur’an okurum. Onun } \\
\text { dışında ekstra bir programa falan gitmedim. Ancak ailem aramamı bekler. Benim kutlamamamın } \\
\text { sebebi, okula başladığımdan beri pek vaktimiz olmuyor. Sınavlar, dersler derken unutabiliyoruz. } \\
\text { Daha cok ailem aradığında aklıma geliyor. }\end{array}$ \\
\hline $\begin{array}{l}\mathrm{K} 3 \\
(\mathrm{~L})\end{array}$ & $\begin{array}{l}\text { Kandiller bir ritüelden çıkıp din haline getirildiği için kutlamıyorum. Kandilleri bir anma günü } \\
\text { olarak düš̈nüyorum ancak insanların o güne özel yaptıkları ibadetleri niceliğe dökmelerini doğru } \\
\text { bulmuyorum. }\end{array}$ \\
\hline $\begin{array}{l}\mathrm{K} 4 \\
(\mathrm{~L})\end{array}$ & $\begin{array}{l}\text { Kutlamıyorum. Kandiller geleneğimizden gelen bir ritüel olarak bugün dinin içine yerleştirilmiş } \\
\text { olduğunu düşünüyorum. }\end{array}$ \\
\hline $\begin{array}{l}\mathrm{K} 5 \\
(\mathrm{~L})\end{array}$ & $\begin{array}{l}\text { Kutlamam. Sebebim ise vicdan ve hissiyatıma oturmayan şeylerde geri duruyorum. Son üç dört } \\
\text { yıldır o günün kandil olduğunu da hissedemiyorum. }\end{array}$ \\
\hline $\begin{array}{l}\text { K6 } \\
(\mathrm{L})\end{array}$ & $\begin{array}{l}\text { Kandil kutlamam. Sadece annemi ve ananemi arıyorum. O da onlar önemsediği için. Benim için } \\
\text { kandiller sıradan bir gün. Benim ailem muhafazakardır. Çocukken sayılarla namaz, dua ilişkisi } \\
\text { üzerinde kurulu bir din algıları vardı. Bu yüz yüz rekât namaz falan gibi ibadetleri var. Böyle şeyleı } \\
\text { beni tatmin etmiyor. Sayı üzerinden din algısını hiç hos bulmuyorum. }\end{array}$ \\
\hline $\begin{array}{l}\mathrm{K} 7 \\
(\mathrm{~L})\end{array}$ & $\begin{array}{l}\text { Kandil kutlarım, ailecek de kutlarız, o günü ibadetle geçiririz. Fakat ben üniversiteye geldiğimden } \\
\text { beri özel bir ritüel yapmıyorum. }\end{array}$ \\
\hline $\begin{array}{l}\mathrm{K} 8 \\
(\mathrm{YL})\end{array}$ & $\begin{array}{l}\text { Denk gelirse, o gün bir işim olmazsa kutlarım. Bunu gereklilikten ziyade böyle şeylerin arada bir } \\
\text { olması iyi olduğu için yaparım. Bize doğuștan gelen bir aktarım var, ailemden gelen bir gelenek } \\
\text { var. Bunu hiç sorgulamadım ama bunun bir zararı olduğunu düşünmediğim için kutluyorum. }\end{array}$ \\
\hline $\begin{array}{c}\text { K9 } \\
\text { (YL) }\end{array}$ & $\begin{array}{l}\text { Her zaman değil ama kutlarım. O geceye değer veririm. Kandiller manevi olarak insanı rahatliyor, } \\
\text { huzur veriyor, farklı bir atmosfer oluyor. Aileden gelen bir gelenek de var. Bu sebeple kutluyorum }\end{array}$ \\
\hline $\begin{array}{l}\text { K10 } \\
(\mathrm{YL})\end{array}$ & $\begin{array}{l}\text { Kutlarım. Benim için sonradan gelişen bir konu kandil kutlamak. Dönüş yaptıktan sonra biraz daha } \\
\text { ilgimi çekti. Beni en çok kandil kutlamaya iten sebep ödül rivayetleridir. "Şu kandilde şunu } \\
\text { yapmanın şu günahların affına sebep olur" gibi rivayetler. Ben de bunun karşıllı̆̆ında bir ödü } \\
\text { alacağımı düşündüğüm için kutluyorum. Hadis dersleri aldıktan sonra özellikle çok daha seçici } \\
\text { olmaya başladım. }\end{array}$ \\
\hline $\begin{array}{l}\text { K11 } \\
(\mathrm{YL})\end{array}$ & $\begin{array}{l}\text { Kutlarım. Rivayetler, gelenekten gelen sebeplerden dolayı kutluyorum. Ailede de özel önem } \\
\text { veriliyor. Herkes kendine çeki düzen veriyor. Gecesinde oruç tutuluyor, akşamını ibadetle } \\
\text { geçirmeye çalışıyorsun bütün işlerini ona göre ayarlıyorsun. Bir nevi insanı rahatlatan bir gece } \\
\text { oluyor. }\end{array}$ \\
\hline $\begin{array}{l}\text { K12 } \\
(\mathrm{YL})\end{array}$ & $\begin{array}{l}\text { Kutlarım, kaçırmam. Ben mütedeyyin bir ailede yetiştim. Babam dini ritüelleri yerine getirme } \\
\text { konusunda hassas bir kişi, bizi o şekilde yetiştirdi. Bu iki boyutlu benim için; birinci boyutu içinde } \\
\text { doğduğum aile diğer boyutu kendimin sorgulayarak öğrenmesi. Araştırdığımda kandillerin ben } \\
\text { birçok yönden tatmin eden tarafları oldu. }\end{array}$ \\
\hline $\begin{array}{l}\text { K13 } \\
(\mathrm{YL})\end{array}$ & $\begin{array}{l}\text { Kaçırdığım evreler oluyor. Sürekli bir şekilde kandil kutlarım diyemem. Zaten böyle bir ortamın } \\
\text { içinde doğdum. Kandillere ailem beni teşvik ettikçe ben de özel bir anlam atfettim. Nedenlerin } \\
\text { sorguladıktan sonra inandığımız din bağlamında kutsiyet atfettiğimiz günler olduğunu ve bu } \\
\text { günlerde de daha çok hassas olmanın önemini anladı̆ım günler. Birleştirici bir etken olduğunu } \\
\text { düşündügüüm ve bu yüzden de kutlamaktan ya da o gün için bir şeyler yapmaktan çekinmediğim ve } \\
\text { bunu yaparken kendimi iyi hissettiğim günler olarak görüyorum. }\end{array}$ \\
\hline
\end{tabular}

Tabloda katılımcıların eğitim ve yaş durumlarına göre verilen cevaplarda bir farklılık oluştuğunu söyleyebiliriz. Yüksek lisans okuyan öğrencilerin Kandil gecelerini kutlama alışkanlıklarının lisans öğrencilerine göre daha oturmuş ve hatırlatılmasa dahi kişisel bir ritüel olarak kabul görüldüğünü ifade edebiliriz. Ancak bunun neden yaptıkları veya yapmadıkları konusunda bir 
ayrışma söz konudur. Katılımcılardan 7 kişi (K1, K2, K3, K4, K5, K6, K8), Kandil gecelerini kutlamamalarına gerekçe olarak; üniversite hayatı ve derslerin yoğunluğunu, büyük şehirde yaşıyor olmanın getirmiş olduğu bir rahatlığın oluştuğunu, aileden uzak olmaktan dolayı bu geceleri hatırlatıcı unsurların azaldığını öne sürmüşlerdir. Yine katılımcılardan K6 ve K4, Kandil gecelerinin İslam'da yerinin olmadığını, bu gecelerin gelenekten çıkıp din haline getirildiğini, İslam'ın içine sonradan yerleştirildiğini ifade etmişlerdir. Bu ifadelerden anlaşılacağı üzere doğrudan dinî olmayan, geleneksel olarak sonradan ortaya çıkmış olan geceler gençler tarafından kutsal kategorisinde yer alınmasına rağmen o gecelere gösterilen ihtimam yeteri düzeyde değildir. Verilen cevaplar kutsal ifadesinin kişi, eşya, yer, zaman vb. kavramlarla birlikte sekülerleştiğini göstermektedir. Bu durum kutsala yüklenen anlamın rutinleşmekte olduğunu ve bu haliyle kutsalın saygı duyulması gereken doğal kültürel fenomenler içerisinde değerlendirildiği göstermektedir.

K6'nın kutlamamasına gerekçe olarak belirtmiş olduğu şu ifadeler muhafazakâr ailelerde yetişen bireylerin ev ortamından ayrıldıktan sonra neden bu gecelere özel bir önem atfetmediklerini de ortaya koyan bir yaklaşımdır; "Benim ailem muhafazakardır. Çocukken sayılarla namaz, dua ilişkisi üzerinde kurulu bir din alglları vard. Bu yüz rekât namaz falan gibi ibadetleri var. Böyle şeyler beni tatmin etmiyor. Sayı üzerinden din algısını hiç hoş bulmuyorum”. Tabloya göre katılımcılarının eğitim durumu ve yaş skalası yükseldikçe Kandil gecelerine daha fazla değer verildiği, firsat buldukça o geceyi bireysel bir ibadet ile geçirmeye gayret edildiği, o güne ait ritüellerin yapılmaya çalış1ldığ 1 gözlemlenmiştir. Yüksek lisans öğrencisi olan K10'un şu ifadeleri ise lisans öğrencisi olan K6'nın bu geceleri kutlamama gerekçesi olarak belirttiği sebeplerin tam zıddı yönünde bir ön kabule sebep olduğunu gösteren ilginç bir yaklaşımdır; "beni en çok Kandil kutlamaya iten sebep "ödül" rivayetleridir. "Şu kandilde şunu yapmanın şu günahların affina sebep olur” gibi rivayetler. Ben de bunun karşılığında bir ödül alacağımı düşündüğüm için kutluyorum”.

Gençlerin kandil gecelerine atfettiği niteliklere dayanarak söyleyecek olursak, din ve dinî geceler olgusu sosyal psikolojik bir perspektifle tanımlanarak, seküler hayat içerisinde insan faktörünü ön planda tutan bireysel değerler kutsal kategorisi içinde değerlendirilmektedir. Gençlerin "kutsal" kavramına yüklediği anlamların birbirinden farklı olması, kutsal gecelere olan alg1 düzeylerini de etkilemektedir. Bu durum kutsal kavramının dinî ve sosyokültürel değerlerle birlikte modern-seküler değerleri içine alacak kadar geniş bir anlam kayması yaşadığını göstermektedir. Bireyler kutsalı, hem din tarafindan mübarek kılındığı için hem de dinî bir saygıya, hayranlığı, korkuya neden olduğu için dinî bir fenomen olarak algılanmaktadır (Yapıc1, 2004). 
Tablo 3: Katılımcıların Zihninde Dini Geceler Olan Kandil Gecelerinin Neyi Çağrıştırdığı ve O Güne Özel Hangi Ritüelleri Gerçekleştirdiklerine Dair Görüşleri:

\begin{tabular}{|c|c|}
\hline $\begin{array}{l}\mathrm{K} 1 \\
(\mathrm{~L})\end{array}$ & $\begin{array}{l}\text { Kandil simidi, bir araya gelme, aile büyüklerini arayıp sormayı çağrıştırıyor. Bizde eskiden kandil } \\
\text { günü babaanneye gidilirdi. O güne özel helva kavurulurdu. Yemekler yapılırdı. Fakat artık bu } \\
\text { gelenek yok. Eskisi gibi toplanılmaz. Sofralar kurulmaz. Şu an özellikle babaannem telefon bekler } \\
\text { kandillerde. Onu ararım mutlaka. Ama annem babam da artık bıraktı sanıyorum. Kutlamadan } \\
\text { ziyade telefonlaşma olarak yapılıyor artık. }\end{array}$ \\
\hline $\begin{array}{l}\mathrm{K} 2 \\
(\mathrm{~L})\end{array}$ & $\begin{array}{l}\text { Kandil simidini ve sayılarla ibadetleri çağrıştırıyor. Tam net bilmiyorum ama şu kadar teşbih } \\
\text { çekersen şu kadar sevap, bu kadar namaz kılarsan bu gece yüz şehit sevabı, akşamla yatsı arasında } \\
\text { şunu yaparsan şöyle olur gibi duyumları çağrıştırıyor. Bir de yüz rekât kandil namazını } \\
\text { çağrıştırıyor. }\end{array}$ \\
\hline $\begin{array}{l}\mathrm{K} 3 \\
(\mathrm{~L})\end{array}$ & Anmayı çağrıştırıyor. O güne özel bir ritüelim yok. \\
\hline $\begin{array}{l}\mathrm{K} 4 \\
(\mathrm{~L})\end{array}$ & Herhangi bir kişiyi veya olayı hatırlamak, anmak. Herhangi bir ritüelim yok. \\
\hline $\begin{array}{l}\mathrm{K} 5 \\
(\mathrm{~L})\end{array}$ & $\begin{array}{l}\text { Kandil simidi, mutlu bir gün, bayram havası gibi bir atmosferi çağrıştırıyor. Ancak hiç de öyle } \\
\text { olmuyor. Ne bayramı ne de kandil günlerini özel hissediyorum. O Güne özel bir şey yapmıyorum. }\end{array}$ \\
\hline $\begin{array}{l}\text { K6 } \\
(\mathrm{L})\end{array}$ & $\begin{array}{l}\text { Kötü yağda pişmiş kandil simidi, TRT'de yerde oturan amcaların musiki söylemesini çağrıştırıyor. } \\
\text { O güne özel hiçbir şey yapmam. }\end{array}$ \\
\hline $\begin{array}{l}\text { K7 } \\
(\mathrm{L})\end{array}$ & $\begin{array}{l}\text { Kandil simidi, TV'de okunan akşam ilahileri, mevlithanlar. O güzel özel her kandilde olmasa da } \\
\text { oruç tutarım. }\end{array}$ \\
\hline $\begin{array}{l}\mathrm{K} 8 \\
(\mathrm{YL})\end{array}$ & Kandil namazını çağrıştırıyor. O güne özel namazımı kılarım, duamı ederim, camiye giderim. \\
\hline $\begin{array}{l}\text { K9 } \\
(\mathrm{YL})\end{array}$ & Camii, cemaatle namazı çağrıştırıyor. O gün müsaitsem camiye giderim. \\
\hline $\begin{array}{l}\text { K10 } \\
(\mathrm{YL})\end{array}$ & Tevbe ve affı çağrıştırıyor. Büyükleri ararım o gün, dua ederim. \\
\hline $\begin{array}{l}\text { K11 } \\
(\mathrm{YL})\end{array}$ & $\begin{array}{l}\text { Oruç tutmayı çağrıştırıyor. O gün akşamında bir cemaatin hem sohbetinde hem zikrinde bulunmaya } \\
\text { çalışıorum. Fırsat buldukça büyük camilere gitmeye çalssıyorum. Kaza namazlarını kılmaya } \\
\text { çalışıyorum. O günler büyükleri ararım, oruç tutarım ve akşamından ibadet yaparım. Kandil mesajı } 1 \\
\text { atarım. }\end{array}$ \\
\hline $\begin{array}{l}\text { K12 } \\
(\mathrm{YL})\end{array}$ & $\begin{array}{l}\text { Rabbimle baş başa kaldığım bir zaman dilimini. Özellikle Berat Kandil’inde bu yaşıma kadar yüz } \\
\text { rekât namazı kılmadığım kandil olmadı diyebilirim. Hala kılıyorum. Oruç da kıymet verdiğim bir } \\
\text { ibadet. Kandil geceleri daha çok benim içime döndüğüm gündür. O gün daha çok içimde o günün } \\
\text { önemini tekrarlarım, kulluk serüvenimi gözden geçiririm. Kur'an okurum. }\end{array}$ \\
\hline $\begin{array}{l}\text { K13 } \\
(\mathrm{YL})\end{array}$ & $\begin{array}{l}\text { Yanan bir mum gibi düşünmüşümdür hep, Işık, fener, mum gibi şeyleri çağrıştırıyor. Bu günlerin } \\
\text { nicelikten çok nitelikli geçirmenin daha önemli olduğunu düşünüyorum. O güne özel yaptı̆̆ım bir } \\
\text { șey yok, oruç tutabilirsem tutarım. Büyükleri ararım ama bunu yapmamın sebebi tamamen onların } \\
\text { gönlünü hoş tutmak için. Daha çok inzivaya çekilme, kendi özüne dönme gibi sorgulamalar } \\
\text { aklımdan geçiyor. }\end{array}$ \\
\hline
\end{tabular}

Tabloyu incelediğimizde Kandil gecelerinin çağrışımlarına katılımcılar farklı farklı cevaplar vermişlerdir. Bunları; kandil simidi, dua, ibadet, anmak, hatırlamak, hatırlatmak, oruç, o geceye has k1lınan namazlar, cami, mevlithanlar, cemaatle kılınan namaz, tövbe, af, yanan mum, kandil olarak özetleyebiliriz. Bu gecelerde yapılan ritüellere baktığımızda katılımcıların \%90'ı o gün için aile büyüklerinin telefon beklediğini, onları arayarak ailelerinin beklentilerini karşıladıklarını belirtmişlerdir. Telefon tebriğinden sonra ikinci bir önem atfedilen ritüel ise o gece tutulan oruçlardır. Görüşmeye katılan lisans öğrencilerinin hemen hemen tamamı (K1, K2, K3, K4, K5, K6) o geceye dair özel bir ritüellerinin olmadığını belirtmişlerdir. Yüksek lisans öğrencilerinin (K9, K10, K11, $\mathrm{K} 12, \mathrm{~K} 13$ ) o geceye dair ritüellerine baktığımızda; oruç, büyükleri arama, camiye gitme, inzivaya çekilme gibi ritüelleri yerine getirdiklerini ifade etmişlerdir. Bir katılımcı ise, (K12) o gece yüz rekâtlık kandil namazı kıldığını belirtmiştir. Bir üstteki tabloda görüldüğü gibi burada da eğitim ve 
yaş durumu değiştikçe dini ritüellerin daha fazla gerçekleştirildiği ve o gecelere daha özel bir önem atfedildiği gözlemlenmektedir.

Katılımcıların vermiş olduğu cevaplara göre Recep ve Şaban aylarından düzenli olarak olmasa da ara sıra nafile oruç tutulmaktadır. Katılımcılardan lisansüstü öğrencilerinin lisans öğrencilerine göre cami, dernek veya vakıflar tarafından düzenlenen dini sohbet ve programlarına daha fazla iştirak ettiği, kadınlara göre ise erkeklerin bu programlara katılımlarının daha fazla olduğu gözlemlenmiştir. $\mathrm{Bu}$ durum özellikle toplumda kadınların erkeklere göre camilere daha az gitmelerinin makbul olduğu dini yorumundan etkilenmesinin bir sonucu olarak da okunabilir. Görüşme sonuçlarına göre kandil gecelerine inanma ve buna uygun davranışlarda bulunma durumu lisansüstü öğrencilerinden daha fazla görülmektedir. Bu durum yaş ilerledikçe dindarlaşma oranında artış olduğuyla ilgili kanaatlere uygun düşmektedir.

\subsection{Mevlid Kandili Anlamı}

Mevlid Kandili, yazılı kaynaklara göre Mısır'da Şii Fâtimi Devleti döneminde kutlanmaya başlanan törenleri ve tazimleri içermektedir (Özel, 2004). Müslüman toplumları için kutsal kabul edilen bu geceler, her toplumun kendi dini yaşayış ve algılayışına göre farklı sembolik ifade ve ritüellerle kutlanmıştır. Türkiye'de Mevlid Kandili, Hz. Peygamber'in doğumu ile ilişkilendirilmiş, ona olan saygının, sevginin bir tezahürü olarak kabul görmüştür. Bu manada katılımcıların Mevlid Kandili’nin kendileri için ne ifade ettiği ve bir ritüel olarak kandil kutlamanın gerekliliğine dair görüşlerinin öğrenilmesi hedeflenmiştir.

Katılımcıların Mevlid Kandili’nin kendilerine ne ifade ettiğine dair görüşlerinin sorulduğu soruya öğrencilerin tamamı; "Hz. Peygamber'in doğumu”, "dünyaya teşrifi”, "doğumunun kutlanması" gibi cevaplar vermiştir. Diğer öğrencilerden farklı olarak katılımcılardan K4 ve K6 bu soruya şu şekilde cevap vermiştir:

Tablo 4: Katılımcıların Mevlid Kandili’nin Kendilerine Ne İfade Ettiğine Dair Görüşleri:

\begin{tabular}{|c|l|}
\hline $\begin{array}{l}\text { K4 } \\
\text { (L) }\end{array}$ & $\begin{array}{l}\text { Mevlid Kandili Peygamberimizin doğumuna ithafen kutlanıyor fakat Peygamber efendimizin } \\
\text { kesin doğum tarihini bilmek neredeyse imkansıdır, bu yüzden benim için ayrı bir anlamı yok. } \\
\text { İlla onu belirli bir günde hatırlamak ve anmak isteyenler için kutlanmasında herhangi bir } \\
\text { sakınca görmüyorum. }\end{array}$ \\
\hline K6 & $\begin{array}{l}\text { Diğer günlerle aynı bir gün. Benim için herhangi bir önemi ve özelliği yok, aksine gereksiz } \\
\text { bir süreç. Peygamberimizin doğumu elbette önemli, ama daha önemli olan insanları bu } \\
\text { hayatta yaşarken neler yaptığıdır. Onun doğumunu kutlamak yerine insanlar kendi hayatlarını } \\
\text { düzeltmeye bir adım atsa daha iyi olur }\end{array}$ \\
\hline
\end{tabular}

Katılımcıların vermiş olduğu cevaplar Mevlid Kandili'nin Hz. Peygamber'e karşı duyulan saygı ve sevginin bir ifadesi olarak bütün İslam toplumlarında bir araya gelinerek sosyalleşme işlevi gördüğünü göstermektedir. Mevlid kutlamalarının bilgilendirme, kültürel ve toplumsal moral gibi birçok fonksiyonu vardır. Bu fonksiyonlarıyla mevlid, toplumun maneviyatının güçlenmesine, bireylerin o değerler etrafinda birleşmesine vesile olduğunu ifade etmektedir.

Tabloya baktığımızda Mevlid Kandili'nin katılımcıların tamamı tarafından $\mathrm{Hz}$. Peygamber'in doğumuna ilişkin bir cevap verildiğini görmekteyiz. Ancak katılımcıların Mevlid Kandili ile Kutlu Doğum Haftası arasında nasıl bir ilişki kurdukları ve aralarında ayrıma ne derece hâkim oldukları tam olarak anlaşılamamıştır. Katılımcılar Hz. Peygamber'e sevgi ve bağlılığın bir ifadesi olarak çeşitli ibadet ve kutlamaların dini yönden meşru bir davranış olduğu yönünde mutabık bir görüş belirtmişlerdir. Ancak bu gecenin kutlanmasına dair K6 ve K4 farklı bir görüş belirtmiştir. Birinci görüşe göre (K6) Hz. Peygamber'in doğduğu günün net olarak bilinmesi imkânsız olduğu için bu gecenin özel bir anlamı da yoktur. İkinci görüşe göre ise, (K4) Kandil günlerinin diğer günlerden bir farkı yoktur zira Hz. Peygamber'in doğumundan ziyade yaşarken insanların ne yaptığı, onun örnekliği ile hayatlarını nasıl düzenledikleri daha önemlidir. 


\subsection{Kutlu Doğum Haftası Faaliyetleri}

İslâm dünyasında Hz. Muhammed'in doğumunun kutlandığı Kutlu Doğum Haftası, Türkiye'de ilk kez 1989'da Türkiye Diyanet Vakfı Mütevelli Heyeti tarafından yayın kurulu kurma görevi verilen Prof. Dr. Süleyman Hayri Bolay'ın kurulu tarafından düşünülmüş ve uygulanmaya başlanmıştır (Bolay, 2007). Türkiye Diyanet Vakfı (Kervancı, 1999). 1989'da tarihinde köklü bir geçmişe sahip olan mevlid geleneğini 'Kutlu Doğum Haftası' adı altında tertip ederek Hz. Peygamber'in doğumunun modern dönem imkanları ile ihya edilmesini ve ona olan saygının bir ifadesi olarak sürdürülmesini amaçlamıştır. Ancak toplumsal bir karşılığı olup olmadığını ortaya çıkartacak ampirik çalışmalar, konunun toplumun bireylerini ne kadar içine dahil ettiği ve özümsediğini kavramak açısından oldukça önemlidir. Araştırmanın alt problemlerinden üçüncüsü olan Türkiye'deki üniversitelerde okuyan öğrencilerin Mevlid Kandili sebebi ile Kutlu Doğum Etkinlikleri çerçevesinde yapılan programlara karşı tutumları belirlenmeye çalış1lırken katılımcılara yöneltilen aşağıdaki sorular çerçevesinde Kutlu Doğum Haftasında gerçekleşen bu ritüellerin toplumdaki farklıkları, çatışmaları, ayrışma ve bölünmeleri ortadan kaldırıp kaldırmadığı konusundaki beklenti, görüş ve öneriler öğrenilmeye çalışılmıştır. Bu manada olması gerekenden ziyade olanın anlaşılması için ortaya konan sorular, olgusal bir gerçeklik olarak kutlama, tören, ayin, ritüel ve mitlerin toplumsal karş1l1klarını sosyolojik olarak betimlemeyi hedeflemektedir.

Tablo 5: Katılımcıların Kutlu Doğum Haftası Etkinliklerine Katılıp Katılmadıklarına Dair Görüşleri:

\begin{tabular}{|c|c|}
\hline $\begin{array}{l}\mathrm{K} 1 \\
(\mathrm{~L})\end{array}$ & $\begin{array}{l}\text { Geçmişte katılmıștım. İlkokuldayken okul götürmüştü bir kere. Tiyatro tarzı bir gösteri olmuştu. } \\
\text { En son ilkokuldayken katıldım sanıyorum. Şu an üniversitede kulüpler yapıyorlar. Ama hiç } \\
\text { katılmadım. }\end{array}$ \\
\hline $\begin{array}{l}\text { K2 } \\
\text { (L) }\end{array}$ & Lise son da katılmıştım. Onun dışında hiç katılmadım. Hiçbir belediye etkinliğine de katılmadım. \\
\hline $\begin{array}{l}\mathrm{K} 3 \\
(\mathrm{~L})\end{array}$ & Çocukken gittiğimiz bir derneğin etkinliklerine 3-4 kere katılmıştım. \\
\hline $\begin{array}{l}\text { K4 } \\
(\mathrm{L})\end{array}$ & Küçükken birkaç kez katıldım. \\
\hline $\begin{array}{l}\mathrm{K} 5 \\
(\mathrm{~L})\end{array}$ & $\begin{array}{l}\text { İmam hatip döneminde camide kutlu doğum programı organize etmiştik. En son katılmışlığım odur. } \\
\text { Üniversite yıllarımda katılmadım. }\end{array}$ \\
\hline $\begin{array}{l}\text { K6 } \\
(\mathrm{L})\end{array}$ & Çocukken elbette gitmişimdir. Ama şu an takip etmiyorum ve gitmiyorum. \\
\hline $\begin{array}{l}\mathrm{K} 7 \\
(\mathrm{~L})\end{array}$ & $\begin{array}{l}\text { Lise de okul camiye götürmüştü. Küçükken cami programlarına gitmişimdir ancak şu an okurken } \\
\text { katılmıyorum. }\end{array}$ \\
\hline $\begin{array}{l}\text { K8 } \\
(\mathrm{YL})\end{array}$ & Okulla bir program yapmıştık. En son dört sene önce katılmıştım. \\
\hline $\begin{array}{l}\text { K9 } \\
(\mathrm{YL})\end{array}$ & Üç sene önce okulda çocuklarla bir program düzenlemiştik. \\
\hline $\begin{array}{l}\text { K10 } \\
(\mathrm{YL})\end{array}$ & $\begin{array}{l}\text { Ben de üç sene önce katıldım ancak bir daha katılmama kararı aldım. Kıbrıs'ta Yakın Doğu } \\
\text { Üniversitesi düzenliyordu. Kandil gecelerinin protokolün kendini gösterme etkinliğine çevrilmesi } \\
\text { gibi bir durum oldu. O programdan sonra bir gitmeme kararı aldım. }\end{array}$ \\
\hline $\begin{array}{l}\text { K11 } \\
\text { (YL) }\end{array}$ & $\begin{array}{l}\text { Biz kendimiz salon programı yapıyorduk. } 15 \text { Temmuz'dan sonra bir daha yapmadık. Yapmayı da } \\
\text { düșünmüyoruz. Kutlu doğum etkinliklerine katılmıyorum. }\end{array}$ \\
\hline $\begin{array}{l}\text { K12 } \\
(\mathrm{YL})\end{array}$ & $\begin{array}{l}\text { Kutlu doğum adı altında yapılan programlara katılmadım. Ancak hicri takvime dek gelen Mevlid } \\
\text { kandili ile ilgili programlara katıldım. Geçtiğimiz Mevlid programını kendi okulumuzda biz } \\
\text { organize ettik. Ona da katıldım. }\end{array}$ \\
\hline $\begin{array}{l}\text { K13 } \\
\text { (YL) }\end{array}$ & Hiçbir etkinliğe katılmadım. \\
\hline
\end{tabular}

Turkish Studies - Education, 15(3) 
Tabloya göre katılımcıların tamamı (13) şu an için herhangi bir Kutlu Doğum etkinliğine katılmadıklarını ancak çocukken veya lise dönemlerinde okul etkinliklerine iştirak ettiklerini belirtmişlerdir. Özellikle salon programlarından ziyade bu katılımın daha çok okul etkinlikleri adı altında yapılan programlara yönelik olduğu ifade edilmiştir. Katılımcılardan lisans okuyan öğrenciler, (K1, K2, K3, K4, K5, K6) son y1llarda Kutlu Doğum Haftas1 etkinliklerini takip etmediklerini, okul derslerinin yoğunluğu nedeni ile de bu etkinlikleri öncelemediklerini belirtmişlerdir. Katılımcı öğrencilerden K12, öğretmen olması sebebi ile her sene düzenli olarak Mevlid Kandili'ne dek gelecek şekilde programlar organize ettiklerini ve kendisinin de bu etkinliklere katıldığını ancak daha önce salon programlarına katılmadığını ifade etmiştir.

Türk toplumunun birliği ve beraberliğinin sağlanması açısından oldukça önemli bir yere sahip olan din olgusu ile sosyal bütünleşme kavramı arasındaki ilişkiye baktığımızda, Hz. Peygamberin doğumu etrafinda yapılan kutlamaları ifade eden "kutlu doğum" faaliyetleri ile sosyal bütünleşme arasındaki ilişkiye yönelik algının özellikle lisans öğrencileri nezdinde oldukça düşük düzeyde olduğu gözlemlenmiştir. Kutlu Doğum Haftası çerçevesinde yapılan tören, ibadet ve sosyal faaliyetlerin gençleri ortak duygu etrafinda birleştirme konusunda yetersiz olduğu ancak yapılan programlara iştirakten ziyade onların organizatörlüğünü üstlenme gibi sorumlulukların gençler arasındaki sosyal çatışma ve ayrışmaları giderici bir fonksiyon üstlendiği görülmektedir.

Tablo 6: Katılımcıların Kutlu Doğum Haftası Etkinliklerini Kutlamanın ve Hz. Peygamber'in Doğumunun Bir Etkinlik Olarak Kutlanmasının Gerekli Olup Olmadığına Dair Görüşleri:

\begin{tabular}{|c|c|}
\hline $\begin{array}{l}\mathrm{K} 1 \\
(\mathrm{~L})\end{array}$ & $\begin{array}{l}\text { Gerekli olduğunu düşünmmüyorum. Bunun bireysel olarak yapılmasını, Peygamberin gelişinin bir } \\
\text { devri nasıl değiştirdiğini, bunu ne kadar önemli bir şey olduğunu düşünmek daha mantıklı geliyor. } \\
\text { Fakat bunu sembolleştirmek, kutlamak farklı bir şey. Bence kutlanmamalı. Ancak kutlayan varsa } \\
\text { karışmam. Ortadan kaldırılsın demek bence çok yanlıs bir şey. Başkasının neyi ne şekilde } \\
\text { kutladığına karışmam. Herkes dini algılamakta ve yaşamakta özgürdür. }\end{array}$ \\
\hline $\begin{array}{l}\mathrm{K} 2 \\
(\mathrm{~L})\end{array}$ & $\begin{array}{l}\text { Gerekli olduğunu düşünmüyorum. Peygamber sevgisi bir günde verilebilecek veya anlatılabilecek } \\
\text { bir olgu değildir. }\end{array}$ \\
\hline $\begin{array}{l}\text { K3 } \\
(\mathrm{L})\end{array}$ & $\begin{array}{l}\text { Kutlu doğum haftasını peygamber efendimizi anma açısından önemli buluyorum. Ama bugünü } \\
\text { etkinlik olarak kutlamak yerine onun misyonunu hayatımızın her alanında uygulamamızı daha } \\
\text { önemli buluyorum. Zaten bunu yapmamız onu andığımız ve hiç unutmadığımız anlamına geliyor. }\end{array}$ \\
\hline $\begin{array}{l}\text { K4 } \\
(\mathrm{L})\end{array}$ & $\begin{array}{l}\text { Peygamberimizi anmak sadece bir güne sıkıştırılmamalıdır. Onun misyonunu hayat taşımak en } \\
\text { güzel anma biçimidir. }\end{array}$ \\
\hline $\begin{array}{l}\text { K5 } \\
(\mathrm{L})\end{array}$ & $\begin{array}{l}\text { Ülkemizde siyaset aktif ve din de daha ağır basıyor. İnsan olarak düşündüğümde bir günle } \\
\text { sinırlandırılabilir ama bir devlet zihniyeti ile düşündüğümde yapılması gereklidir. Hz. Peygamberin } \\
\text { doğumu etkinlik olarak kutlanacaksa pasta koyup mum üfleyerek değil de daha çok akademik } \\
\text { düzeyde seminer tarzında hayatı anlatılabilir. }\end{array}$ \\
\hline $\begin{array}{l}\text { K6 } \\
(\mathrm{L})\end{array}$ & $\begin{array}{l}\text { Ben bu soruyu üç kısma ayırdım; birincisi kişisel olarak bence gereksiz bir etkinlik, ikincisi bir } \\
\text { devlet adamı olsam daha iyisini yapardım. Dini açıdan ise eğer bir etkinlik yapılacaksa da böyle } \\
\text { yapılmaması lazım. Bu seminer veya akademik çalışmalarla olmaz. Basma kalıp ifadelerle Hz. } \\
\text { Peygamber tanıtılamaz. Bu yaşanılarak öğrenilen bir süreçtir. }\end{array}$ \\
\hline $\begin{array}{l}\mathrm{K} 7 \\
(\mathrm{~L})\end{array}$ & $\begin{array}{l}\text { Yapılan programlar hatırlatma ve o günü diğerlerinden özel kılmak için yapılabilir şu an ki yapılan } \\
\text { siyasetçilerin eli ile ise gereksiz. Kutlu Doğum bir etkinlik olarak değil de akademik düzeyde bir } \\
\text { sunum olarak yapılabilir. Kutlama havasında olmamalı. }\end{array}$ \\
\hline $\begin{array}{l}\mathrm{K} 8 \\
(\mathrm{YL})\end{array}$ & $\begin{array}{l}\text { Gerekli olduğunu düşünmüyorum, artık tadı kaçtı. Etkinlik olarak kutlanmamalıdır. Yaptıkları, } \\
\text { hayatı falan elbette aktarılmalı ama farklı bir şekilde. }\end{array}$ \\
\hline $\begin{array}{l}\text { K9 } \\
(\mathrm{YL})\end{array}$ & Dini bir gereklilikten dolayı yapılmasını değil fakat faydalı olduğunu düşünüyorum. Kutlanmalıdır. \\
\hline $\begin{array}{l}\text { K10 } \\
(\mathrm{YL})\end{array}$ & Gerekli olduğunu düşünmüyorum. Salon programı dışında olabilir. \\
\hline $\begin{array}{l}\text { K11 } \\
(\mathrm{YL})\end{array}$ & $\begin{array}{l}\text { Yapılması gerektiğini düşünüyorum. Özellikle gençlerimize Peygamberimizi biraz daha } \\
\text { hatırlatmak babında bu tarz etkinliklerin hiçbir mahsuru yok diye düşünüyorum. Ancak salon } \\
\text { programı olarak kutlanmamalı. }\end{array}$ \\
\hline
\end{tabular}


K12 Ben o haftanın kutlanması gerektiğini düşünüyorum. Özellikle okullarda çocuklarda farkındalık (YL) oluşturmak adına bu tarz etkinliklerin önemli olduğunu düşünüyorum.

K13 Kuşaklar arası aktarım ve yeni gelen nesile bir şeyleri hatırlatmak babında kutlanılabilir diye

(YL) düşünüyorum. Bu şekilde insanların gözünde peygamber algısı daha olumlu bir konuma konulabilir. Türkiye'de etkinlik olarak faydalı ve olması gerektiği gibi olmadığını düşündüğüm için kutlanmamalıdır.

Tabloya göre kat1lımc1lardan 9’u (K1, K2, K3, K4, K6, K7, K8, K10, K13), Kutlu Doğum Haftası etkinliklerinin ve Hz. Peygamberin doğumunun bir etkinlik olarak kutlanmasını gerekli görmemektedir. Katılımcılardan K5, K9, K11, K12 ise Kutlu Doğum Haftası'nın kutlanmasını gerekli olarak görmüşlerdir. Bu haftayı kutlamanın gerekli olmadığını düşünenler kendi içlerinde farklı gerekçeler ve çözüm önerileri sunmuşlardır. Katılımcılardan K3 ve K4 bu önemli gecenin bir etkinlik olarak kutlanmasından ziyade Hz. Peygamberin misyonunun hayata taşınmasının daha önemli olduğunu ifade etmişlerdir. Katılımcılardan K6, bu kutlamaların gereksiz olduğunu şu ifadelerle gerekçelendirmiştir: "Ben bu soruyu üç kısma ayırdım; birincisi kişisel olarak bence gereksiz bir etkinlik, ikincisi bir devlet adamı olsam daha iyisini yapardım. Dini açıdan ise eğer bir etkinlik yapılacaksa da böyle yapılmaması lazım. Bu seminer veya akademik çalışmalarla olmaz. Basma kalıp ifadelerle Hz. Peygamber tanitılamaz. Bu yaşanılarak öğrenilen bir süreçtir." Katılımcılardan K5'in ifade ettiği gerekçelerden biri ise; siyaset eli ile salon programlarına taşınan bu tarz etkinliklerin faydasız olacağı ve siyası rant malzemesine dönüşeceği düşüncesidir. Katılımcılardan K7'nin vermiş olduğu şu cevap ise bir Kutlu Doğum etkinliğinin nasıl olması gerektiğine dair öneri ve eleştiri içermektedir: "Hz. Peygamberin doğumu etkinlik olarak kutlanacaksa pasta koyup mum üfleyerek değil de daha çok akademik düzeyde seminer tarzında hayatı anlatılabilir." Katılımcılardan bu etkinliklerin yapılmasının gerekli olduğunu düşünenlerden K5, K9, K11 bunu birtakım şartlara bağlamışlardır; kutlamaların siyaset eli ile olmadığı, dini bir gereklilik olarak görülüp zorunlu hale getirilmediği sürece kutlanabilir olduğunu ifade etmişlerdir. Kutlanmasının gerekli olduğunu ifade eden K11 ve K12, bunun gerekçesini gençlerimize farkındalık katmak ve onlara Hz. Peygamber'i hatırlatmak olarak belirtmişlerdir. Bu kutlamaları gerekli görmeyen katılımcılardan K13 ise, gerekçe olarak Türkiye'deki bu etkinlikleri faydalı bulmadığını ancak kuşaklar arası aktarımda nesilden nesile taşınan bir hatırlatma olarak kutlanabilirliğinin olması gerektiğini ifade etmiştir. 
Tablo 7: Katılımcıların Kutlu Doğum Haftası Etkinliklerinin Devlet ve Siyaset Eli ile Salon Programlarına Taşınarak Kurumsallaşmasına Dair Görüşleri:

\begin{tabular}{|c|c|}
\hline $\begin{array}{l}\mathrm{K} 1 \\
(\mathrm{~L})\end{array}$ & $\begin{array}{l}\text { Devlet eliyle yapılan bu etkinliklerin bir beklenti içerisinde yapıldığını düşünüyorum. Toplumun } \\
\text { en çok benimsediği kutsal saydığı şeylere yatırım yapmak elbette planlı ve stratejik bir şeydir. Ben } \\
\text { ilime bilime ve topluma faydası olmayan bütün hizmetlere yapılan harcamaların israf olduğunu } \\
\text { düşünüyorum. }\end{array}$ \\
\hline $\begin{array}{l}\mathrm{K} 2 \\
(\mathrm{~L})\end{array}$ & $\begin{array}{l}\text { İsraf olarak görüyorum. Geri dönüş aldıkların düşünmüyorum. İnsanlar bir gün böyle bir şeye } \\
\text { kat1lıp sonra tekrar yaşamlarına geri dönüyorlar. Bunun devlet eliyle yapılmasını siyasi bir unsur } \\
\text { olarak görüyorum. Asla masum olduğunu düşünmüyorum. }\end{array}$ \\
\hline $\begin{array}{l}\text { K3 } \\
(\mathrm{L})\end{array}$ & Devlet eliyle hatılatılması güzel bir şey ancak kurumsallaşması şart değil. \\
\hline $\begin{array}{l}\text { K4 } \\
(\mathrm{L})\end{array}$ & $\begin{array}{l}\text { Peygamberimizin doğumu, devlet ve siyaset eli tarafından kurumsallaştırlabilecek bir "etkinlik" } \\
\text { olamaz. }\end{array}$ \\
\hline $\begin{array}{l}\text { K6 } \\
(\mathrm{L})\end{array}$ & Siyasi tarafi çok olduğunu düşünmüyorum. Bu bir zihniyetin sonucu. \\
\hline $\begin{array}{l}\mathrm{K} 7 \\
(\mathrm{~L})\end{array}$ & Devlet eliyle yapılması eğer siyasetçiler göz önünde olmasa, o programlarda bence iyi bir şey. \\
\hline $\begin{array}{l}\mathrm{K} 8 \\
(\mathrm{YL})\end{array}$ & $\begin{array}{l}\text { Gereksiz bir şey bu. Ancak hangi iktidar gelirse gelsin bu kutlamaları yapacağını düşünüyorum. } \\
\text { Burada yapılan harcamaları israf olarak görüyorum. }\end{array}$ \\
\hline $\begin{array}{l}\text { K9 } \\
(\mathrm{YL})\end{array}$ & $\begin{array}{l}\text { İki yönlü cevap verebilirim. Olumlu yanı dini hayatın kurumsal alana taşınarak benimsenmesi ve } \\
\text { normalleşmesi din adına iyidir. Kötü olan kısmı ise dinin siyasi malzeme olarak kullanılması dine } \\
\text { zarar verir. Nesneleştirir. }\end{array}$ \\
\hline $\begin{array}{l}\text { K10 } \\
(\mathrm{YL})\end{array}$ & $\begin{array}{l}\text { Kıbrıs'ta kandillerin tamamı resmî tatil, bu tarz etkinlikler devlet eli ile yapılıyor. Halk manevi } \\
\text { olarak peygamberine çok bağlı ancak protokol geliyor herkes de onu alkışlıyor. Bu biraz } \\
\text { sömürülüyor. Türkiye'de çok farklı olacağını sanmıyorum. }\end{array}$ \\
\hline $\begin{array}{l}\text { K11 } \\
\text { (YL) }\end{array}$ & $\begin{array}{l}\text { Devlet eli olması gerekir. Bunu STK'larla da yapabilirsiniz, ancak bunu Diyanet ile yapmak daha } \\
\text { doğru geliyor bana. }\end{array}$ \\
\hline $\begin{array}{l}\text { K12 } \\
(\mathrm{YL})\end{array}$ & $\begin{array}{l}\text { Diyanet devletten ayrı bir kurum değil, devletin bu işlere bakan kurumu olduğu için devlet eliyle } \\
\text { yapılması gerekir diyorum. İsraf boyutunda ise abartılmamak kaydı ile israf olduğunu } \\
\text { düşünmüyorum. }\end{array}$ \\
\hline $\begin{array}{l}\text { K13 } \\
(\mathrm{YL})\end{array}$ & $\begin{array}{l}\text { Dinin tek ele alınmasına karşıyım hatta Diyanet'in bile varlığını sorgularım. Dinin devlet tekelinde } \\
\text { veya kurumlar odaklı bu şekilde insanlara bir şeyler anlatmasının biraz ideolojik olduğunu } \\
\text { düşünüyorum. Siyasi tarafa çekilebilir bir ucu olduğunu, insanların gönüllerini hoş tutan şeylerin } \\
\text { aşırıya kaçılmamak üzere yapılmasında bir sakınca olmadığını düşünüyorum. }\end{array}$ \\
\hline
\end{tabular}

Tabloya göre katılımcılardan 11 kişi (K1, K2, K3, K4, K5, K6, K7, K8, K9, K10, K13), Kutlu Doğum Haftası etkinliklerinin devlet ve siyaset eli ile salon programlarına taşınarak kurumsallaşmasını onaylamadıklarını ifade etmişlerdir. Katılımcılardan K11 ve K12 ise devlet eli ile olması gerektiğini belirtmişlerdir. Devlet ve siyaset eli ile bu kutlamaların yapılmaması gerektiğini ifade eden katılımcıların buna getirmiş olduğu gerekçelerin başında; dini içerikli programların devlet ve siyaset eli ile istismar edilmesidir. Diğer önemli bir gerekçe ise bu etkinliklerde yapılan harcamaların "israf" olarak değerlendirilmesidir. Devlet ve Diyanet eli ile yapılmasının gerekli olduğunu ifade eden K11 ve K12 ise bu gerekliliği devletin dini alanlarda hizmet veren kurumu olan Diyanet'in bu görevi siyasilerden ziyade kendisinin üstlenmesi gerektiğini ifade etmişlerdir. Katılımcılardan K1'in vermiş olduğu şu cevap bu etkinliklerinin devlet eli ile neden kurumsallaşmaması gerektiğinin bir göstergesidir: "Devlet eliyle yapılan bu etkinliklerin bir beklenti içerisinde yapıldığını düşünüyorum. Toplumun en çok benimsediği kutsal saydığı şeylere yatırım yapmak elbette planlı ve stratejik bir şeydir. Ben ilime bilime ve topluma faydası olmayan bütün hizmetlere yapılan harcamaların israf olduğunu düşünüyorum." Katılımcılardan K13 ise, dinin devlet tekelinde kurumlar odaklı bir hizmet sunmasının ideolojik bir boyutu olduğunu şu ifadelerle yanıtlamıştır: "Dinin bir kurum tarafindan yönetilmesine karşılyım hatta Diyanet'in bile varlığını sorgularım. Dinin devlet tekelinde veya kurumlar odakl bu şekilde insanlara bir şeyler anlatmasının biraz ideolojik olduğunu düşünüyorum. Siyasi tarafa çekilebilir bir ucu olduğunu, insanların 
gönüllerini hoş tutan şeylerin aşırıya kaçılmamak üzere yapılmasında bir sakınca olmadı̆̆ını düşünüyorum”.

\subsection{Kutlama ve Dini Sembollerin Metalaşması}

Din sosyolojisi değer yargısı üzerinden dini veya dinleri araştırmaz; din ile sosyal olanın etkileşimini ve bu etkileşimden doğan davranış tiplerini ve davranış modellerini betimler; olması gereken değil olanın üzerinde çalışır. Toplumda birleştirici-bütünleştirici veya çatışmacı- ayrıştırıcı sonuçlar doğuran olay ve olgulara, iyi-kötü-, değerli-değersiz şeklinde peşin hükümler vermek din sosyolojisinin görevi değildir. Dolayısıyla sosyoloji “olan”"ın tasvirini yaparak olgusal gerçekliğin sosyolojik betimlemesini yapmakla yükümlüdür (Akarsu, 2016). Bu manada dini ritüellerin toplumdaki genç kesim ile karşılıklı etkileşimi üzerinden bir sonuca varmak için katılımcılara yöneltilen aşağıdaki sorular bağlamında dinin belli bir kültürel forma bürünerek sembollerle kendini yeniden üretmesinin tüketim toplumunda nasıl algılandığının öğrenilmesi hedeflenmektedir.

Farklı bir pazarlama biçimi olarak ifade edilen "dini pazarlama (religious marketing)" sekülerleşme ekseninde din sosyolojisinin son dönemlerde üzerinde durduğu bir konudur. Kapitalizm kültürünün bir sonucu olarak ortaya çıkan tüketim odaklı yaşam beklentisi, dinin yeni bir formda ve şekilde izah edilmesine yol açmıştır. Bu anlayış dinin yaratıcıya dair bir sorumluluk olarak algılanmasından çıkıp ikonizmi çağrıştıran kutlamalar ile vitrinde yaşanan tüketimsel bir objeye dönüşmesine neden olmuştur. Tüketim ve din bağlamında katılımcılara yöneltilen aşağıdaki soru; dini unsurların metalaşması ile inanç arasında hesabi bir ilişki var mıdır? Tüketim toplumunda toplum tarafindan muteber kabul edilen inanç, örf, adet ve geleneklerin onayından geçmiş ritüeller devletin din ile kurduğu ilişki biçimini gösterir mi? Bu çerçevede Müslüman olan Türk toplumu açısından modern ayin ve kutlamalar anlamın içinin boşaltıldığı ritüelistik bir dinin yaşanmasına ve Hz. Peygamber'in özne konumundan nesne konumuna indirgenmesine sebep olur mu gibi sorulara cevap aranmiştır. 
Tablo 8: Katılımcıların, Kutlu Doğum ve Mevlid Programlarının Hz. Peygamber’i Tanıtmaktan Ziyade Onun Bir Pazarlama Unsuruna Dönüştürüldüğüne; Ona Atfedilen Nesne ve Objelerin Kutsiyet Atfedilerek Metalaştırıldığına; Bu Tarz Etkinliklerin Onun Misyonunu Arka Plana Atarak Kabuğa İndirgendiğine Dair Fikirlere Katılıp Katılmadıklarına İlişkin Görüşleri:

\begin{tabular}{|c|c|}
\hline $\begin{array}{l}\mathrm{K} 1 \\
(\mathrm{~L})\end{array}$ & $\begin{array}{l}\text { Metalaşamadığını söyleyemem. Özellikle bu haftalara dek gelerek basılan kitap satışları, salon } \\
\text { programlarında satılan bu gibi unsurlar metalaştırıldığını gösteriyor. }\end{array}$ \\
\hline $\begin{array}{l}\mathrm{K} 2 \\
(\mathrm{~L})\end{array}$ & Zor bir soru, evet sanıyorum metalaşıyor. \\
\hline $\begin{array}{l}\text { K3 } \\
(\mathrm{L})\end{array}$ & $\begin{array}{l}\text { Evet katılıyorum. Anlamdan çok kazanca dönüştüğ̈̈̈nü düşünüyorum. Bence kutsallık atfedilen } \\
\text { semboller Peygamber efendimizin misyonunun önüne geçiyor ve bu etkinlikler asıl amacından } \\
\text { sapiyor. }\end{array}$ \\
\hline $\begin{array}{l}\mathrm{K} 4 \\
(\mathrm{~L})\end{array}$ & $\begin{array}{l}\text { Evet katılıyorum. Peygamberimize ait olduğu düşünülen eşyalar kutsal kabul edilip günümüzde } \\
\text { ticari amaçla kullanılıyor. Burada önemli olan peygamber efendimize atfedilen saç kılını, } \\
\text { hırkayı, misvağı vs. günümüze taşımak değil onun misyonunu günümüze taşımaktır. }\end{array}$ \\
\hline $\begin{array}{l}\text { K5 } \\
(\mathrm{L})\end{array}$ & $\begin{array}{l}\text { Hz. Peygamberin satıcılar tarafından metalaştırıldığını düşünüyorum. Halkımız onu meta olarak } \\
\text { gördüğü için yapmıyor. Bizim toplum olarak dini figürlere saygı seviyemiz çok yüksek. Şu an } \\
\text { Peygamber efendimizin sakalı şerifi gelse hiçbir şey hissetmesek bile toparlanırız. Sayg1 } \\
\text { duyuyoruz. Ezan da böyledir. Bunlar metalaşmaktan ziyade saygının getirdiği durum. }\end{array}$ \\
\hline $\begin{array}{l}\text { K6 } \\
(\mathrm{L})\end{array}$ & $\begin{array}{l}\text { Herhangi bir değer atfedilen obje toplum tarafindan zaman içerisinde metalaştırılır. Fakat } \\
\text { toplumun daha bilinçli olması bunun önüne geçebilirdi. Toplum kendini kullandırırsa bu gibi } \\
\text { şeylerin satıcısı da bol olur elbette. }\end{array}$ \\
\hline $\begin{array}{l}\mathrm{K} 7 \\
(\mathrm{~L})\end{array}$ & $\begin{array}{l}\text { Metalaştığını düşünüyorum. Sadece kandillerde değil normal zamanlarda da satış unsuru olarak } \\
\text { pazarlanıyor. Bal, çörek otu yağı gibi şeylerin Peygamberin hadislerine atıfla TV kanallarında } \\
\text { satılması bunun yapıldığını gösteriyor. Bu görüşe katılıyorum. }\end{array}$ \\
\hline $\begin{array}{l}\mathrm{K} 8 \\
(\mathrm{YL})\end{array}$ & $\begin{array}{l}\text { Ben de çok fazla katılmasam da katılıyorum. Türkiye'de yapılan güven araştırması sonuçları } \\
\text { Hz. Peygamberin daha iyi tanıtılmadığını gösteriyor ve misyonunu zedeliyor. }\end{array}$ \\
\hline $\begin{array}{l}\mathrm{K} 9 \\
(\mathrm{YL})\end{array}$ & $\begin{array}{l}\text { Evet katılıyorum dini değerlerin maddi kaygılarla kullanılmasına karşıyım. Bunun haram } \\
\text { olduğunu düşünüyorum. Insanların bu duruma karşı bilinçlendirilmesini düşünüyorum. Hatta } \\
\text { mümkünse devletin buna sınırlandırma getirmesini isterim. }\end{array}$ \\
\hline $\begin{array}{l}\text { K10 } \\
(\mathrm{YL})\end{array}$ & $\begin{array}{l}\text { Pazarlama olarak katılıyorum. Televizyonda bir kanalda bal reklamında bile bunun örneklerini } \\
\text { görüyoruz. } \mathrm{Bu}, \mathrm{Hz} \text {. Peygamberin misyonunun asıl öğretisini perdeliyor. }\end{array}$ \\
\hline $\begin{array}{l}\text { K11 } \\
(\mathrm{YL})\end{array}$ & $\begin{array}{l}\text { O ürünlerin satışına ilgi duymuyorum ve böyle bir şeyi de doğru bulmuyorum. İnsanlar o } \\
\text { ürünleri aldığında kendisini Hz. Peygambere yakın hissediyor. Ona da bir şey diyemiyorum. O } \\
\text { ona peygamberi hatırlattığı için onu almıştır. Ancak bunu kullananlar iyi niyetli değil. Bu çok } \\
\text { boyutlu ve tartışılacak bir konu. Ben o görüște olanlara göre ortada duruyorum. }\end{array}$ \\
\hline $\begin{array}{l}\text { K12 } \\
(\mathrm{YL})\end{array}$ & $\begin{array}{l}\text { Bu görüşün ortaya çıkmasını anlamak çok zor değil. Bunu bidat olarak da görebiliyorlar. } \\
\text { Onların söylediklerini tamamen yok da saymıyorum fakat katılmıyorum da. Ortada bir yer de } \\
\text { duruyorum. Bunların hitap ettiği kesimin eğitim seviyesi önemli bir noktadır. Din genel olarak } \\
\text { metalaşmış bir kavram olarak önümüzde duruyor. Din adına hizmet ettiğini söyleyen birçok } \\
\text { kesim bunu yapıyor. }\end{array}$ \\
\hline $\begin{array}{l}\text { K13 } \\
(\mathrm{YL})\end{array}$ & $\begin{array}{l}\text { O görüşte olanlara katılıyorum yalnız şöyle bir ayrım yapabilirim, her toplumda din en çok } \\
\text { sömürülmeye müsait bir yapı olarak ön plana çıkıor. Ben Marx'ın "din toplumların afyonudur” } \\
\text { sözüne kendimi yakın hissediyorum. Bizim ülkemizde özellikle. Dini eğitim noktası burada çok } \\
\text { önemli bir husus. Bir kesim Peygamberi İslam'ın bir tık üstüne çıkarttığı ve onu mitolojik bir } \\
\text { unsura dönüştürdügü için insanlar da metalaştırmaya başlıyor. }\end{array}$ \\
\hline
\end{tabular}

Tablo incelendiğinde katılımcıların tamamına yakını, Kutlu Doğum ve Mevlid programlarını Hz. Peygamber'i tanıtmaktan ziyade onun bir pazarlama unsuruna dönüştürüldüğünü; ona atfedilen nesne ve objelerin kutsiyet atfedilerek metalaştırıldığını belirtmişlerdir. Ancak verilen cevaplarda açık şekilde bir "metalaşma"nın gerçekleştiğini ifade eden kat1lımciların say1s1 8 (K1, K3, K4, K5, K6, K7, K9, K10)'dir. Kat1limciların Hz. Peygamber'e atfedilen yiyecek, sembolik figürler veya nesnelerin "kutsiyet" atfedilerek pazarlanmasına karş1 tutumlarında örnek verilerek bu görüşün desteklenmesi söz konusu olmuştur. Özellikle lisans öğrencileri bu görüşü daha fazla desteklemekte ve katıldıklarına dair farklı örneklerle görüşün 
çerçevesine genişletmektedirler. Mevlid ve Kutlu Doğum etkinliklerinde dağıtılan gül, koku, Hz. Peygamber'e atfedilen sakal'ı şerîf, misvak, takke, cübbe, esans, yanmayan kefen gibi örnekler bunlardan birkaçıdır. Yine salon programlarında satışa sunulan Hz. Peygamber ile ilgili kitaplar, broşürler; TV kanallarında pazarlanan çörek otu, çörek otu yağı, bal gibi "kutsiyet" atfedilen yiyecekler de bunlara ilave olarak belirtilmiştir. Katılımcılardan K3, metalaşmanın Hz. Peygamber' in misyonuna zarar verdiğini şu cümleler ile ifade etmiştir: "Evet katıllyorum. Anlamdan çok kazanca dönüştüğ̈̈nü düşünüyorum. Bence kutsallık atfedilen semboller Peygamber efendimizin misyonunun önüne geçiyor ve bu etkinlikler asıl amacından sapıyor."

Katılımcılardan K5, K11, K12 metalaşmanın kısmi olarak var olduğunu ancak bunun gerekçesinin içinde bulunduğumuz toplumun Hz. Peygamber'e dair hissettiği masumane sevgi ve saygının bir ifadesi olduğunu söylemişlerdir. Bu metalaşmanın satıcılar tarafindan yapıldığını ancak alıcıların tamamen safiyane niyetlerle bunu aldığını ve farkında olarak metalaştırmadıklarını belirtmişlerdir. Metalaşmanın dini eğitimle orantılı bir algı olduğunu ifade eden K13 ise, konuya farklı bir bakış açısıyla yaklaşarak, Hz. Peygamber'i mitolojik bir kahraman olarak tarihi bir figüre dönüştürerek ulaşılamaz bir konuma iten zihniyetin de bunda payının olduğunu şu cümlelerle ifade etmiştir: "O görüşste olanlara katıllyorum yalnız şöyle bir ayrım yapabilirim, her toplumda din en çok sömürülmeye müsait bir yapı olarak ön plana çıkıyor. Ben Marx'ın "din toplumların afyonudur" sözüne kendimi yakın hissediyorum. Bizim ülkemizde özellikle. Dini eğitim noktası burada çok önemli bir husus. Bir kesim Peygamberi İslam'ın bir tık üstüne çıkarttığ ve onu mitolojik bir unsura dönüştürdügü için insanlar da metalaştırmaya başlyyor."

Tablo 9: Katılımcıların Etkili Bir Kutlu Doğum Etkinliğinin Nasıl Olması Gerektiğine ve Böyle Bir Etkinliğe Konuşmacı Olarak Kimi Getirmek İstediklerine Dair Görüşleri:

\begin{tabular}{|c|c|}
\hline $\begin{array}{l}\text { K1 } \\
(\mathrm{L})\end{array}$ & $\begin{array}{l}\text { Ben olsam etkinliği etkinlik olarak yapmazdım. Benim önerim ancak bir etkinliğe dönüşmemesi } \\
\text { yani bir etkinlik yapılmamasıdır. }\end{array}$ \\
\hline $\begin{array}{l}\text { K2 } \\
(\mathrm{L})\end{array}$ & $\begin{array}{l}\text { Her kandilde aynı şeyleri yapmak yerine peygamberi anımsatan, onun hayatında etkili olup, } \\
\text { herkesin merak edip de okumayacağı bir kesiti ele alarak işlerdim. Bu konuda kaynak } \\
\text { Kur'an'dan olmalıdır. İnsanların hayatına etki edecek bir Kur'an pasajı, ayeti olabilir. Engin } \\
\text { Noyan sanıyorum. }\end{array}$ \\
\hline $\begin{array}{l}\text { K3 } \\
(\mathrm{L})\end{array}$ & $\begin{array}{l}\text { Kuran-1 Kerim'den faydalanarak peygamberi en doğru şekilde anlatabilmeyi ve misyonunu } \\
\text { hayatımıza geçirebilmeyi hedefleyen etkinlikler yapardım. Bayraktar Bayraklı, Mustafa } \\
\text { İslamoğlu. }\end{array}$ \\
\hline $\begin{array}{l}\mathrm{K} 4 \\
(\mathrm{~L})\end{array}$ & $\begin{array}{l}\text { En doğru ve en güvenilir siyer kaynağı olarak Kur'an yeterlidir. İnsanlar Kur'an’1 okuyarak } \\
\text { peygamber efendimizi ve onun misyonunu en iyi şekilde ögrenebilirler. İsrafil Balcı, Mehmet } \\
\text { Okuyan. Kendileri sahih hadislerden istifade etmekle birlikte peygamber efendimizi anlatırken } \\
\text { Kur'an'ı öncelikli kaynak olarak ele alıyor. }\end{array}$ \\
\hline $\begin{array}{l}\text { K5 } \\
(\mathrm{L})\end{array}$ & $\begin{array}{l}\text { Siyasi lider kesinlikle olmalı. Akademik seviyelerde bir anlatım olabilir. Halk düzeyinde ise } \\
\text { satıcılığa girecek biraz ama kapı kapı dolaşıp insanlara gül vererek hediye vererek peygamber } \\
\text { anlatılabilir. Konserler düzenlenebilir. Kesinlikle reisi cumhur gelmeli, açılış programına } \\
\text { Mehmet Görmez gelebilir. }\end{array}$ \\
\hline $\begin{array}{l}\text { K6 } \\
(\mathrm{L})\end{array}$ & $\begin{array}{l}\text { Bence iftar, salon kapatmak, program yapmak gibi etkinlikler israf. İlla bir gösteri olacaksa onu } \\
\text { sosyal medya üzerinden, Youtube üzerinden yapabilirim. }\end{array}$ \\
\hline $\begin{array}{l}\mathrm{K} 7 \\
(\mathrm{~L})\end{array}$ & $\begin{array}{l}\text { Seminer olabilir, halkın sevdiği biri gelip konuşma yapabilir. Ama faydalı olur mu } \\
\text { bilemiyorum. }\end{array}$ \\
\hline $\begin{array}{l}\mathrm{K} 8 \\
(\mathrm{YL})\end{array}$ & $\begin{array}{l}\text { Hiç düşünmedim. Sanırım Muhammed Emin Yıldırım’ı çağırırdım. Nasıl bir etkinlik yapardım } \\
\text { bilemiyorum. }\end{array}$ \\
\hline $\begin{array}{l}\text { K10 } \\
(\mathrm{YL})\end{array}$ & $\begin{array}{l}\text { Ben bir konuşmacı tutacak olsam Nihat Hatipoğlu'nu seçerdim. Halkın anlayacağı şekilde hitap } \\
\text { eden bir konuşmacı. Ancak bana böyle şeyler çok boş geliyor. İslam deklarasyonunda şöyle bir } \\
\text { mesaj vardı, "cami minarelerinden verilen mesaj ile uydu vericilerinden mesaj çatıştı̆ı sürece } \\
\text { boşa mücadele ediyoruz". Adam camiden çıkınca eve gidip dizi izliyor. Asıl bu kısımla } \\
\text { mücadele etmek gerekiyor. }\end{array}$ \\
\hline $\begin{array}{l}\text { K11 } \\
\text { (YL) }\end{array}$ & $\begin{array}{l}\text { Elimde olsa bütün insanları Medine'ye götürmek isterdim. Konuşmacı olarak Mustafa Akgül } \\
\text { olabilir, Muhammed Emin Yıldırım olabilir. }\end{array}$ \\
\hline
\end{tabular}




\begin{tabular}{|c|l|}
\hline $\begin{array}{c}\text { K12 } \\
\text { (YL) }\end{array}$ & $\begin{array}{l}\text { Hitap edilen kesime göre içeriği değişken olurdu. Kaynağım Diyanet olurdu. Hz. Rasulullah'ın } \\
\text { hadisleri aktarılabilir. Benim kafadaki kişi bazlı değil de daha kolektif bir program olurdu. } \\
\text { Rasulullah'taki insan sevgisini anlatarak, insanları ocu bucu diye ayırmadan ortak bir çatı } \\
\text { altından toplayan bir peygamber imgesini onlara anlatmak gerektiğini düşünüyorum. Şu an isim } \\
\text { gelmedi aklıma. Orda birisini oturtup şunu konuş demek bana pek faydalı gelmiyor. }\end{array}$ \\
\hline $\begin{array}{c}\text { K13 } \\
\text { (YL) }\end{array}$ & $\begin{array}{l}\text { Kaynak olarak Kur'an'ı alırdım ama kişi konusunda aklıma kimse gelmiyor. Kur'an'dan } \\
\text { Peygamber efendimizi anlatan ayetleri ele alırdım. }\end{array}$ \\
\hline
\end{tabular}

Tabloya baktığımızda katılımcıların tamamının etkili bir Kutlu Doğum etkinliğinin nasıl olması gerektiğine ve böyle bir etkinliğe konuşmacı olarak kimi getirmek istediklerine dair görüşlerinde benzerlikler ortaya çıkmıştır. Kutlu Doğum etkinliklerinin, panel, sempozyum, konferans gibi toplumu bilgilendirici faaliyetler içermesi katılımcılar tarafından çok daha fazla önemsenmektedir. Programda işlenen konular konusunda Hz. Peygamber'in farklı bir yönünü ön palana çıkartacak, onun daha iyi tanınmasını sağlayacak içeriklerin aratılması yönündeki kanaatler ön plana çıkmaktadır. Konuşmacıların niteliklerine yönelik soruya ise katılımcılar, konuşmacının titri, makamı, uzmanlık alanı, anlatacağı konuya hâkim olması ve popülerliği üzerinden bir tercihte bulunmuştur.

Kat1lımc1lardan K2, K3, K7, K12, K13 bu haftadaki etkinliklerin bir kutlama ve tören havasından ziyade ilmi konuşmalar, konferanslar, paneller ile yapılması gerektiğini belirtmişlerdir. Katılımcılardan K1, bu haftanın "etkinlik" olarak yapılmaması gerektiğini, bu geceyi bir etkinlik havasında kutlamanın doğru olmadığını belirtmiştir. Yine katılımcılardan K2, K3, K4, K13 bu gecede Kur'an'dan Hz. Peygamber'i tanitan pasajların okunmas1, onu anlatan birinci kaynak olan Kur'an'dan istifade edilmesinden yana fikir beyan etmişlerdir. Katılımcıların etkili bir Kutlu Doğum etkinliğine kimi davet edecekleri konusunda verdiği cevaplar ise birbirinden farkl1lık arz etmektedir.

\section{Sonuç ve Tartışma}

"Mevlid" geleneği ve Kandil geceleri, bin yılı aşkın bir süredir var olan bir geleneğin ürünü olarak İslam coğrafyalarında yoğun ilgiye mazhar olmuştur. Kutlu Doğum Haftası etkinlikleri bu tarihi temayüllerin modern bir yansıması olarak günümüz İslam toplumlarının hemen hemen birçok şehrinde uygulanmaktadır. Mevlid geleneği, kültürel kodların nesilden nesile aktarılması ile oluşan fonksiyonel bir işleve sahiptir. Bu işlev toplumun farklı kesimlerini ortak bir paydada birleştirerek onu sosyal bir gerçeklik ve olguya dönüştürmüştür.

Yaygın olarak kabul gören dini yaşayış ve inanç sistemleri, bir toplumdaki dini hayatın ritüellerini belirlemede, özelliklerini ve işlevselliğini tanımlamada, inancın hangi esas ve ilkelere dayandırılarak sürdürülmesinde önemli bir işlevsel konuma oturmaktadır. Araştırmanın alt problemleri doğrultusunda katılımcıların ortaya koymuş olduğu görüşler; toplumun farklı sosyal çevrelerinin kültürel arka planlarını, dini algı ve alışkanlıklarını belirlemede temel unsurun "kutsal" ve o kutsala olan saygının fiili bir tezahürü olduğunu ortaya çıkarmıştır. M. Eliade, tören ve kutlama geleneğinin insanoğlunun soyut olanı "maddeleştirme" arzusundan kaynaklandığını, bireylerin kutsal ile olan iliş̧isinin onu yüceleştirme, ululama, daha üst bir konuma yerleştirerek ritlerin canlandırılması ve anlam kazanması olarak ifade eder (Eliade M. , 1991). Bu maddeleştirme veya nesneleştirme; idealize edilen hedeflerin, rol modellerin, ulaşılması güç prototiplerin gündelik hayatta çeşitli simge ve formalarla ifade edilerek yaşatılma arzusudur.

Bu çalışmada cevabı aranan temel sav, belirli bir dine inanan insanların "kutsal" atfedilen gün ve gecelere dair davranış ve tutumlarında bir değişiklik olup olmadığı, bu gecelerde yerine getirilen ritüellerin kültürel kodlarla gelen bir rol davranış mı yoksa dini bir gereklilik mi olduğunun ortaya konulmasıdır. Bahsi geçen dini davranış ve tutumlar, bireylerin kültürel geçmişlerine ait birikimlerinden uygun bir "norm" ve "ön kabul" mekanizması oluşturmakta mıdır? Bu anlayışın bir tezahürü olarak belirli zamanlara ve mekanlara kutsallık atfedilmekte midir? Kutlu Doğum Etkinlikleri çerçevesinde bir kutlama ve şölene çevrilen "Mevlid" kandili Hz. Peygamber'i yeterince 
tanıtıyor mudur yoksa tanıtmaktan ziyade getirmiş olduğu mesajı arka plana atarak onu kutsal bir mitolojik kahramana $\mathrm{m} 1$ çeviriyordur? Tüm bu soruların cevabının arandığı çalışmada yapılan görüşmelerden ortaya çıkan sonuç tezimizin geçerliliğini ve güncelliğini koruması açısından oldukça önemlidir.

Araştırmanın alt problemleri çerçevesinde katılımcıların vermiş olduğu yanıtlar Kutlu Doğum ve Mevlid-i Nebî etkinliklerinin Hz. Peygamber'i yeterince tanıtıp tanıtmadığı, coğrafya, kültür ve geleneğin bireylerin dini gün ve gecelere yükledikleri anlam ile doğru orantılı olup olmadığ 1 , eğitim ve yaş değişkenlerinin bireylerin dini tutumlarında farklılık oluşturup oluşturmadığ konusunda tartışmaya açılmasını gerekli kılmaktadır.

Katılımcıların vermiş olduğu cevaplar çerçevesinde ortaya çıkan problemler maddeleştirilerek tartışmaya ve değerlendirmeye sunulmuştur:

- $\quad$ Araştırmanın birinci alt problemi doğrultusunda katılımcılara yöneltilen "kutsal nedir? " sorusu; Tanrı tarafından verilen, dokunulmaz, ulaşılması güç, manevi bir yönü olan değerler bütünü olarak ifade edilmiştir. Kutsalın ahlakî olan ile bağlantısı irdelendiğinde rasyonel olmayan bir alana tekabül ettiği görülür. Kutsalın bir diğer ifadesi ise, tüm dinlerin ortak noktasında yer alıyor olmasıdır. Her dinin kendi kelimelerinde, kendi dilinde, kendi alışkanlıkları ve geleneklerinde mutlaka "kutsal" ifade eden bir tezahür vardır. "Kutsal bir başkasının deneyimlediği kendi mistik tecrübesine karşı hoşgörü ve saygıyı gerektirir mi?" sondaj sorusuna karşı katılımcıların çoğu, başkasının kutsalına karşı saygının ahlaki bir gereklilik olduğunu, kutsiyet atfedilen bir olguya karşı eleştiri yapmanın karşı tarafı rahatsız edeceği hatta kıracağına dair ortak bir görüş birliği vardır. Ortaya çıkan sonuca göre din, kutsal kabul edilen insanüstü nesneleri tecrübe etme şekillerinin farklılaştığı bir sistemdir. Kutsal, bütün zaman ve mekanlarda insanların dokunulmaz kabul ettiği ve sayg1 duyduğu bir olgu, bireylerin dini motivasyon ve gücünü kendisinden aldığı tecrübî ve mistik bir güçtür.

- $\quad$ Araştırmanın ikinci alt problemi olarak katılımcılara yöneltilen "Kandil gecelerini kutlar mısınız? "' sorusuna verilen cevaplar, şekilsel olarak bir kutlama ve tören havasında olmasa da içsel bir sorgulama, arınma, düşünme ve anma isteği uyandırdığ 1 konusunda ortak bir görüş birliği vardır. Ancak araştırmanın iki ayrı odak grup üzerinde yapılmış olmasının sağladığı avantajlardan birisi olan yaş ve eğitim seviyelerine göre farklı cevaplara ulaşabilme imkânı, lisans öğrencilerinin yüksek lisans öğrencilerine göre dini ritüelleri uygulamada daha esnek ve sorgulayıcı olduğunu göstermiştir. Onlara göre dini tecrübe ve kutsiyet atfedilen geceler daha çok geleneğin getirmiş olduğu bir kültürel formdur. Ebeveynlerinin bu gecelere kendilerinden daha fazla önem atfettiğini belirten öğrencilerin birçoğu, sırf onların gönlünü etmek için bu gecelerde aile büyüklerini aradıklarını ifade etmişlerdir. Dolayısıyla aşkın bir gerçeklikle ilişkili olarak bir ayrıma tabi tutulan "Kandil" geceleri, dinin ana unsurları olan namaz, oruç gibi ibadetlerden ilahi kaynaklı olup olmama yönünden ayrılmaktadır. Katılımcıların cevaplarında ortaya çıkan dini tecrübe, gelenekten gelen ritüelleri sorgulamadan yapılan bir taklitten ziyade "üstün varlık" karşısında kişinin kendisini sorumlu hissetmesi ve ona bağlılığını çeşitli ritüeller ile gösterme biçimidir. Tecrübe edilen bu gerçekliğin bireylerin yaşantı ve onları yorumlama biçimine göre farklı oluşu, "kutsal" kabul edilen gün, gece ve zamanların bireye özgü olduğunun bir ifadesidir.

- $\quad$ Araştırmanın üçüncü alt problemi olan kandil gecelerinin çağrışımina ve katılımcıların o güne özel ritüellerine baktığımızda; dini gün ve gecelerin belirli sembolik ifadelerle kendini tanımladığı, o sembollere atıfla o günün Kandil olduğunun anlaşıldığg ortaya çıkmaktadır. Katılımcıların vermiş olduğu cevaplar irdelendiğinde Kandil gecelerinin, bireyler arasında paylaşmayı ve dayanışmayı arttırdığı, aile büyüklerini aramak için hatırlatıcı bir işleve sahip olduğu ortaya çıkmaktadır. Her ne kadar kültürel bir form olarak var olsa da sosyal bütünleşme olarak Kutlu Doğum etkinlikleri toplumun birlik ve beraberliğini geliştirmektedir. Toplumdaki bireyleri suni gündemlerden kısa bir süreliğine de olsa uzaklaştırıp, ideolojik farklılıkları bir kenara bırakıldığı ortak bir platform oluşturmaktadır. Dolayısıyla Kandil gecelerinde yapılan törenler, ayrışma ve 
çatışmayı bir kenara bırakarak bireyleri iyileştirici bir işlevsellik etrafında birleştirici bir potansiyele sahiptir. Katılımcıların o güne özel dini ritüellere sahip olmaması ise günümüz gençleri için bu tarz faaliyetlerin işlevselliğini yitirmesi, dini ritüellerin gösteri ve tören formunda bir unsura bürünmesinin onu özünden uzaklaştıracağı inancı, sahih kaynaklardan günümüze kadar gelmiş olan bağlayıcı bir dini yükümlülüğünün olmaması olarak yorumlanabilir. Verilen cevaplar Mevlid Kandili'nin ilk kez hicretten 350 yıl sonra Şii Fâtimi Devleti döneminde Mısır'da kutlanmaya başladığı bilgisini onaylayan bir niteliktedir.

- $\quad$ Araştırmanın dördüncü alt problemi olan Mevlid Kandili'nin bireyler için ne ifade ettiğinin sorulması üzerine alınan cevapların ortak noktası, Hz. Peygamber'in o haftada, o gecede veya spesifik bir gün olan o gün de yani 12 Rebiulevvel gecesi doğmuş olmasıdır. Bu kutlamaların tarihi bir arka plana sahip olmasının yanısıra özellikle İbn Hacer el-Askalânî, es-Suyûti gibi bazı alimlerin Hz. Peygamber'in dünyaya geldiği bu gecede sevinmenin, muhtaçlara, yolda kalmışlara yardım etmenin, Hz. Peygamber'e şiirler okuyarak bugünü kutlamanın "bid'at-ı hasene" olduğunu ifade etmişlerdir (Yaran, 1992). Bunun tam zıddı bir görüşe sahip olan İbn Teymiye, Muhammed Abduh, Abdillah et-Tuveycîrî gibi alimler de mevlid kutlamanın "bid'at-i seyyie" olduğunu söylemişlerdir (Yaran, 1992). Tüm bu görüşler çerçevesinde katılımcıların konuya yaklaşımı ortada bir yerde durmaktadır. Mevlid Kandili ile Kutlu Doğum Etkinlikleri arasındaki farkın anlaşılması konusunda katılımcılar net bir görüş belirtmemişlerdir. Özellikle lisans öğrencileri Kutlu Doğum Haftası çerçevesinde yapılan kutlamalara bireysel olarak katılmasalar bile, bu geceleri kutlayanlara karşı saygılı olma konusunda hemfikirdirler. Mevlid Kandili özelinde kandil gecelerinin, II.Selim'den itibaren "kandil” adını aldığının; günümüze gelene kadar uğramış olduğu bütün toplum ve kültürlerden bir şeyler eklenerek geleneksel bir forma büründüğünün bilincinde olmak, Kur'an ve sünnette bir karşılığının olmadığını bilerek bu gecelere ilahi ve dogmatik bir "kutsiyet" atfetmeden hatırlamak ve anmak için o günü nitelikli geçirmek ve en önemlisi o günü Müslümanlar tarafından sonradan kutlanmaya başlanmış bir "gelenek" olduğunun bilincinde olarak anmak, bu iki zit görüş arasında konumlanabilecek orta bir yoldur.

- Araştırmanin beşinci alt problemi olan Kutlu Doğum Haftası etkinliklerine bireylerin katılıp katılmadığı sorusuna katılımcıların hemen hemen tamamının cevabı katılmadıkları yönünde olmuştur. Katılımcılar, özellikle belediyelerin organize ettiği salon programlarına gitmediklerini, bu tarz etkinlikleri takip etmediklerini, en son lise döneminde okul içi programlarda yer aldıklarını ifade etmişlerdir. Katılımcıların vermiş olduğu cevaplar, devlet eli ile organize edilen salon etkinliklerine katılan kesimin lisans ve yüksek lisans öğrencilerinden oluşmadığını, bu etkinliklerin hitap ettiği yaş aralığının otuz ve üzeri olduğunu göstermektedir. 13 katılımcı ile sınırlı bir araştırma olan bu çalışmada ortaya çıkan sonuç; bireylerin zihinlerinde, eğitim seviyesi yükseldikçe salon programlarında dini gün ve geceleri kutlamanın gerekliliği konusunda soru işaretleri oluştuğunu göstermektedir. Yine analitik düşünce becerisi geliştirmenin dini pratikteki karşıllı̆ 1 ibadet ve ritüellerin sayılar ve nicelik üzerinden olmadığını, bilakis bireylerin kutsal ile inanç arasındaki ilişkisinin düşünme, anlama ve akletme süreçleri ile doğru orantılı olarak geliştiğini ortaya koymaktadır.

- $\quad$ Araştırmanın altıncı alt problemi olarak sorulan "Kutlu Doğum Haftası ve Hz. Peygamber'in doğumunun bir etkinlik olarak kutlamanın gerekliliği” sorusuna verilen cevaplarda ortaya çıkan sonuç, bu haftada yapılan etkinliklerin gerekli olduğunu düşünenler ile düşünmeyenlerin oranının eşit olduğunu göstermiştir. Ancak lisans (7 kişi) öğrencilerinin tamamına yakını yüksek lisans öğrencilerine göre bu haftadaki yapılan etkinlikleri gereksiz olarak görmüşlerdir. Buna gerekçe olarak, Hz. Peygamber'in salon programlarında tanıtılamayacağını, bu tarz programların onun misyonunu göz ardı edeceğini sunmuşlardır. Hz. Peygamber'i anmak ile anlamanın farklı şeyler olduğunu ifade eden bu görüş̧e göre İlahi Kitab'ın bizden istediği onu 'anmak' değil 'anlamak'tır. $\mathrm{Bu}$ görüş tezimizin ortaya koyduğu "onun örnekliğini çağa taşımak, onu günümüz gençlerine rol model olarak anlatmak devlet eli ile salon programlarında yapılan etkinlikler aractlı̆̆ ile değil, 
onun getirmiş olduğu rehber ve kaynak olan Kur'an’ h hayatın bütününe yerleştirecek bir eğitim modeli inşast ile gerçekleşecektir" fikrini onaylamaktadır.

- $\quad$ Araştırmanın yedinci alt problemi olarak, Kutlu Doğum Haftası'nda yapılan programların devlet ve siyaset eli ile kurumsallaşmasını nasıl değerlendirdiklerine dair katılımcıların vermiş olduğu cevaplar incelendiğinde; siyasilerin eli ile yapılan salon programlarının o gecenin maneviyatını zedelediği, bu tarz dini gecelerin siyasi bir rant aracı olarak kullanıldığ 1 , dinin toplumun yumuşak karnı olması hasebi ile devlet mekanizmasının bu tarz etkinliklere özel bir önem atfettiği ve bu çerçevede toplumun içerisinde oluşması ihtimal çatışma unsurlarının bu şekilde denetlendiği ve sakinleştirici bir işlev gördüğüne dair ortak bir kanaat vardır. Bu etkinliklerin devlet eli yapılması taraftarı olanların ortaya koyduğu gerekçe ise, toplumun bireylerinin maneviyatını geliştirmesi açısından bu tarz dini gün ve gecelere ihtiyaç vardır. Bu görüşte olan katılımcılara göre bu gecelerin toplumdaki farklı düşünceleri bir araya getirebilme gibi işlevsel özellikleri vardır. Ancak bu etkinlikler devlet eli yapılmalı, dini cemaatler, STK'lar ve partilere birakılmamalıdır. Bu tarz etkinlikleri devletin dini kurumu olan Diyanet'in organize etmesi ise güvenilirlik açısından en makul olanıdir.

- Araştırmanın sekizinci alt problemi olan “dinin metalaşması” doğrultusunda katılımcılara sorulan, "Kutlu Doğum ve mevlid programlarının Hz. Peygamber'i tanıtmaktan ziyade onun bir pazarlama unsuruna dönüştürüldüğ̈̈ne; ona atfedilen nesne ve objelerin kutsiyet atfedilerek metalaştırıldığına" dair soruya katılımcıların vermiş olduğu cevaplar mevlid kandili özelinden ziyade dinin her alanında var olan bir "metalaşma"nın olduğunu göstermektedir. Dinin nesneleşmesi ve meta değere indirgenmesi bireylerin din ile kurdukları ilişkinin alış-veriş ilişkisine dayalı, hesabî bir ilişki olduğunu gösteren bir unsurdur. Hayatın her alanında tezahür eden gösterişçi tüketim, dini unsurlarda da nitelikten ziyade nicelik, form, şekil, hacim ve parasal değer üzerinden konumlanmıştır. Bu manada mevcut dini yaşayış tarzının pratiklerinde biçimsel farklılıklar ortaya çıkmakta bunun bir sonucu olarak da bir kesim tarafından Hz. Peygamber'in getirmiş olduğu mesajdan ziyade onun giyim tarzı, saçı, sevdikleri veya sevmedikleri üzerinden bir pazar ekonomisi oluşturulmaktadır. Dini duyguların istismarına açık olan bu alan Hz. Peygamber'in özne iken nesne konumuna indirgenmesine, onun davranışlarının nedenleri ve niçinlerini sorgulamaktan ziyade koyu bir taklitçiliğe neden olmaktadır. Dolayısıyla dindarlığın biçim ve içerik değiştirdiği bu alan, metalaşmanın; TV ekranlarında bal, çörek otu, misvak, yer masası, kabak pazarlamaktan başlayıp dini ibadetlerin sayıya, belirli bir güne, belirli bir saat aralığına indirgenmesine kadar gitmiştir. Sonuç olarak hangi unsurların gelenekten hangilerinin asli unsur olan Kur'anî bir bilgi üzerinden geldiğini anlayacak olan seçip ayıran/mümeyyiz akıl devre dışı bırakılmıştır. Yapılan görüşmede boş zamanları değerlendirmede bir faaliyet alanı açan mevlid programlarının, giderek yalnızlaşan bireylere alternatif bir dini alan inşa ettiği görülmektedir. Dinin piyasada satın alınabilecek bir boş alan aktivitesi haline gelmesi, bireylerin merak etme duygularının pazar ekonomisi tarafindan sömürülmesine, indirgemeci bir yaklaşım ile beşerileşmesine ve profanlaşmasına neden olmaktadır.

- Araştırmanın dokuzuncu alt problemi doğrultusunda katılımcılara yönlendirilen etkili bir Kutlu Doğum etkinliğinin nasıl olması gerektiğine dair görüşler, nitelik açısından Hz. Peygamber'i pasta üfleyerek, mum söndürerek veya musiki eşliğinde anmaktan ziyade onun misyonunu daha iyi anlatacak programların öncelenmesinin önemine vurgu yapmışlardır. Katılımcıların tamamına yakını salon etkinliklerinde illa bir program yapılacaksa bunun Kur'an'dan Hz. Peygamber'i tanıtacak ayetlerin doğru kişiler eliyle aktarılmasının, panel veya sempozyum tarzında bilimsel bir içerikte sunulmasının daha yararlı olacağı ifade etmişlerdir.

Mevlid geleneği İslam coğrafyalarında Hz. Peygamber'in öğretisine sadakatin, onun ulvi vazifesine bir saygının ve dindarlığın bir göstergesi olarak algılanmıştır. Türk geleneklerinde mevlid törenlerinin önemi bir iman tazeleme, dua ve tefekkür vesilesi ve elçiyi getirene bir saygı ifadesidir. Muhafazakâr çevrelerin modern dönem yansıması olarak yeni bir forma soktuğu bu dini gün ve gecelerin işlevselliği dönemsel olarak eski saflığını ve samimiyetini korumuyor olsa da bugün hala bireylerin kendi içsel yolculuğunda derin bir anlamı karşılamaktadır. Bu manada Müslüman Türk

Turkish Studies - Education, 15(3) 
kültüründe kandil geleneğinin gelenekten daha üst bir makamda görülmesi kültürel ve örfi anlayışın bir ürünü olarak kabul edilmektedir.

Hz. Peygamber ile ilgili tüm yaklaşım ve sembolik değerlerin kendisine vurulması gereken mihenk taşı Kur'an'dır. Bu manada İslam dininin tören ve ritüelistik boyutunun bir tezahürü olan "Kandil Geceleri", Hz. Peygamber'e dair bilgileri sahih ve güvenilir kaynaklar aracılığı ile onun misyonunun daha iyi anlaşılması ve hayata aktarılmasına katkı sağlıyorsa; onu çağın tüketim nesnesi olmaktan uzaklaştırıp nesne konumundan özne konumuna taşıyorsa; bireyleri onu tüketmek yerine üreterek, getirmiş olduğu mesaja işaret ederek Kur'an'ı daha iyi anlamaya sevk ediyorsa; onu bir anı, geçmişe ait bir mitolojik unsur gibi anmak yerine getirmiş olduğu mesajı merkeze alarak anlatıyorsa gerçek manada birleştirici ve işlevsel bir misyon içeriyor demektir.

\section{Kaynakça}

Akarsu, A. (2016). Sosyal bütünleşme bağlamında kutlu doğum faaliyetleri. Siirt Üniversitesi Illahiyat Fakültesi Dergisi, 2(2), 101-126.

Allen, D. (1996). Din fenomolojisi. (Çev. M. Katar). Ankara Üniversitesi Illahiyat Fakültesi Dergisi, XXXV, 164. https://doi.org/10.1501/Ilhfak_0000000840

Arslan, M. (2002, Eylül-Aralık). Sosyolojik din tanımları ve din olgusunu anlamada uygun bir kavram olarak kutsal. Tabula Rasa Felsefe-Teoloji (2 (6), 159-172.

Ağaoğlu, Z. E. (2009). Dini ziyaret yerleri ve halk inanışları açısından kizılcıhamam-çamlıdere. (Yüksek lisans tezi). Ankara Üniversitesi Sosyal Bilimler Enstitüsü.

Büyüköztürk, Ş., Aygün, Ö., Kılıç Çakmak, E., \& Karadeniz, Ş. (2016). Nitel araştırma yöntemleri. Pagem Akademik Yayıncılık.

Banarl1, N. S. (1978). Resimli türk edebiyat tarihi. M.E.B. Yayınları.

Baudrillard, J. (1997). Tüketim toplumu. (Çev. H. Deliçaylı ve F. Keskin). Ayrıntı Yayınları.

Bolay, S. H. (2007). Kutlu doğum köklü bir geleneğin modern tarza ihyasıdır. Diyanet Aylık Dergi (198), 14-18.

Bozkurt, N. (2001). "Kandil". TDV İslam Ansiklopedisi (DİA). TDV Yayınları. Cilt: 24. 300-301.

Bozkurt, N. (2012). "Kandil". TDV İslam Ansiklopedisi (DİA). TDV Yayınları. Cilt: 24. 299-300.

Cengil, M. \& Tekin, D.B. (2016). Kutsal zaman, algılanış biçimi ve ibadet hayatına etkisi. Hitit Üniversitesi Ilahiyat Fakültesi Dergisi, 15(29), 33-63. https://doi.org/10.14395/hititilahiyat.258546

Demirci, K. (1997). Dinler tarihinin meseleleri. İnsan Yayınları.

Demirci, K. (2002). "Kutsiyet". TDV İslam Ansiklopedisi (DİA). TDV Yayınları. Cilt: 26. 497.

Durkheim, E. (1965). The elementary forms of the religious life. Free Press.

Durkheim, E. (2005). Dini hayatın ilkel biçimleri. (Çev. F. Aydın). Ataç Yayınları.

Durkheim, E. (2006). Toplumsal işbölümü. (Çev. Ö. Ozankaya). Cem Yayınevi.

Eliade, M. (1995). Kutsal ve dindışı. (Çev. M. A. Kılıçbay). Gece Yayınları.

Eliade, M. (1996). The reality of sacred. D. L. Palls (Der.), Seven theorles of religion. (1) 37. Oxford University.

Eliade, M. (2001). Mitlerin özellikleri. (Çev. S. Rifat). Om Yayınevi. 
Eliade, M. (2003). Dinler tarihine giriş. (Haz. E. Kocabıyı). Kabalcı Yayınevi.

Eliade, M. (2014). Dinin anlamı ve sosyal fonksiyonu. (Çev. M.Aydın). Din Bilimleri Yayınevi.

Eliade, M. (2017). Kutsal ve dindışı. (Çev. A. Berktay). Alfa Yayınları.

Ünver, İ. (2004). "Mesnevi”. TDV İslam Ansiklopedisi (DIA). TDV Yayınları. (Cilt XXIX). 209.

Karadeniz, S. (2018). Bir kavram habitusu denemesi: "kutsal". Uluslarası Sosyal Araştırmalar Dergisi, 11 (56), 376-388.

Karasar, P. D. (2014). Bilimsel araştırma yöntemi. Nobel Yayınları.

Kervanc1, M. (1999). "Kutlu doğum haftası kutlamaları ile ilgili olarak tdv genel müdürü mehmet kervanc1 ile röportaj". Diyanet Aylık. Dergi, 37-40. https://dergi.diyanet.gov.tr/makaledetay.php?ID=18796

Okumuş, E. (2003). Toplumsal değişme ve din. İnsan Yayınları.

Özel, A. (2004). "Mevlid". TDV İslam Ansiklopedisi (DİA). TDV Yayınlar1. Cilt: 29. 475-479.

Özel, A. (2002). Mevlid tarihi ve dinî hükmü. Divan: Disiplinlerarası Çalışmalar Dergisi (12), 235246.

Parmaksızoğlu, İ. (1976). "Mevlid". Türk Ansiklopedisi. Milli Eğitim Basımevi.

Pekolcay, N. (2004). “Mevlid”. TDV İslam Ansiklopedisi (DIA). TDV Yayınları. Cilt 29. 485-486.

Punch, K. F. (2016). Sosyal araştırmalara giriş. Siyasal Kitabevi.

Sharpe, E. J. (2000). Dinler tarihinde elli anahtar kavram. (Çev. A. Güç). Arasta Yayınları.

Toygar, K. (1982). Türkiye'de "mevlid" çevresinde meydana gelen folklorik unsurlar. II. Milletlerarası Türk Folklor Kongresi Bildirileri. Kültür ve Turizm Bakanlığı Milli Folklor Araştırmaları Yayınları. Cilt IV. 518-519.

Vergote, A. (2002). Kutsal (Çev. H. Keskin ve A. Yapıc1). Çukurova Üniversitesi İlahiyat Fakültesi Dergisi 2 (2), 209-235.

Yıldırım, M. (2007). Mircea Eliade'de "kutsal ve kutsal zaman" kavramı. Dini Araştırmalar Dergisi, $10(28), 59-82$.

Yapıcı, Y. D. (2004). Allah ve kutsal kavramlarının çağrıştırdıkları alamlara sosyo-psikolojik bir bakış: çukurova ünivesitesi örneği. Değerler Eğitimi Dergisi (2 (7-8), 169-206.

Yaran, R. (1992). "Bid'at". TDV İslam Ansiklopedisi (DIA). TDV Yayınları. Cilt: 6. 129-131.

Zeydan, C. (2016). İslam uygarlıkları tarihi. (Çev. N. Gök). İletişim Yayınları. 